\title{
Auriferous pyrite formed by episodic fluid inputs in the Akeshi and Kasuga high-sulfidation deposits, Southern Kyushu, Japan
}

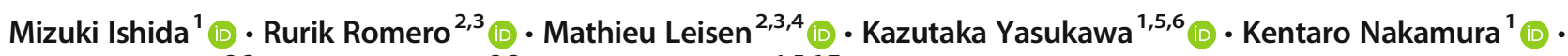 \\ Fernando Barra $^{2,3}$ (D) Martin Reich ${ }^{2,3}$ (D) Yasuhiro Kato ${ }^{1,5,6,7}$
}

Received: 30 October 2020 / Accepted: 15 March 2021 / Published online: 31 March 2021

(C) The Author(s) 2021

\begin{abstract}
Pyrite geochemistry has proven useful for tracking changes in the composition and physico-chemical conditions of hydrothermal fluids in ore-forming environments. Here, we investigated the microtextural features and chemical composition of pyrite, a main Au-bearing phase in the Akeshi and Kasuga deposits (Southern Kyushu, Japan), to better constrain the ore-forming processes in these high-sulfidation epithermal Au deposits. Despite the widespread distribution of Au-bearing pyrite in both deposits, no visible Au minerals coexist with pyrite. However, in situ laser ablation inductively coupled plasma mass spectrometry results show that $\mathrm{Au}$ concentrations in pyrite vary from below the detection limit to $41 \mathrm{ppm}$ and are positively correlated with $\mathrm{Cu}(r=$ 0.4; up to $7400 \mathrm{ppm}$ ) and $\mathrm{Bi}$ concentrations ( $r=0.44$; up to $640 \mathrm{ppm}$ ). In both deposits, high $\mathrm{Cu}$ and Au concentrations occur in small $(<25 \mu \mathrm{m})$ anhedral grains of pyrite, which are interpreted to have rapidly crystallized from the ore-forming hydrothermal fluid. In addition, dissolution-reprecipitation textures and thin, concentric, $\mathrm{Cu}$-rich overgrowths were identified in a number of larger $(>25 \mu \mathrm{m})$ pyrite grains and aggregates. These abrupt changes in the trace element compositions of pyrite grains likely record episodic metal-rich fluid inputs. We also propose that gold adsorption onto growing pyrite surfaces played a key role in the mineralization of these deposits.
\end{abstract}

Keywords Epithermal Au deposits $\cdot$ Pyrite geochemistry $\cdot$ LA-ICP-MS $\cdot$ EPMA $\cdot$ Nansatsu district

\section{Introduction}

Southern Kyushu, Japan, is known for its intense volcanichydrothermal activities related to the subduction of the Philippine Sea plate over the past 5 million years (Watanabe 2005; Mahony et al. 2011). Abundant epithermal Au

Editorial handling: B. Lehmann

Yasuhiro Kato

ykato@sys.t.u-tokyo.ac.jp

1 Department of Systems Innovation, The University of Tokyo, 7-3-1 Hongo, Bunkyo-ku, Tokyo 113-8656, Japan

2 Department of Geology and Andean Geothermal Center of Excellence (CEGA), FCFM, Universidad de Chile, Plaza Ercilla, 803 Santiago, Chile

3 Millennium Nucleus for Metal Tracing Along Subduction, FCFM, Universidad de Chile, Plaza Ercilla, 803 Santiago, Chile

4 Present address: Géosciences Environnement Toulouse(GET), Université de Toulouse, UPS, CNRS, IRD, CNES, 14 avenue E. Belin, 31400 Toulouse, France mineralization is associated with this volcanism, including all four currently mined epithermal Au deposits in Japan (Watanabe 2005; Garwin et al. 2005). Active hydrothermal systems, including Satsuma-Iwojima (Shinohara et al. 1993; Hedenquist et al. 1994a) and Kirishima (Hedenquist and Aoki 1991), have been studied recently, plus the Quaternary

5 Frontier Research Center for Energy and Resources (FRCER), The University of Tokyo, 7-3-1 Hongo, Bunkyo-ku, Tokyo 113-8656, Japan

6 Ocean Resources Research Center for Next Generation (ORCeNG), Chiba Institute of Technology, 2-17-1 Tsudanuma, Narashino, Chiba 275-0016, Japan

Submarine Resources Research Center, Research Institute for Marine Resources Utilization, Japan Agency for Marine-Earth Science and Technology (JAMSTEC), 2-15 Natsushima-cho,

Yokosuka, Kanagawa 237-0061, Japan 
Hishikari low-sulfidation Au deposit (e.g., Izawa et al. 1990; Faure et al. 2002; Morishita et al. 2018; Fig. 1). Other studies have focused on the Pliocene high-sulfidation Au deposits in the Nansatsu district, southern-most Kyushu. Earlier studies have reported ubiquitous pyrite in these deposits (Tokunaga 1954; Nakamura et al. 1994; Hedenquist et al. 1994b) as an important host of primary Au (Imai et al. 1996; Morishita et al. 2019). However, there has been few studies on the microtextural characteristics and the trace element composition of pyrite in these deposits.

Detailed microtextural observations of pyrite combined with in situ geochemical analyses have proven useful in unraveling $\mathrm{Au}$ mineralization processes in ore-forming environments and, particularly, for tracking changes in the composition and physico-chemical conditions of hydrothermal fluids (e.g., Deditius et al. 2008; Reich et al. 2013; Tardani et al. 2017; Román et al. 2019). This is because pyrite (i) is ubiquitous and stable over a wide range of physico-chemical conditions in ore deposits (Deditius et al. 2008, 2014; Reich et al. 2013) and (ii) can incorporate a variety of metals and semi-metals (Cu, $\mathrm{Co}, \mathrm{Pb}, \mathrm{Sb}, \mathrm{As}, \mathrm{Ag}, \mathrm{Au}, \mathrm{Ni}, \mathrm{Zn}, \mathrm{Se}, \mathrm{Te}$, and $\mathrm{Hg}$, among others) either in solid solution or as micro- to nano-sized inclusions depending on its formation conditions (Deditius et al. 2011, 2014; Román et al. 2019). Moreover, pyrite has been recognized as an important host of $\mathrm{Au}$ in ore deposits because pyrite can absorb and incorporate $\mathrm{Au}$ from fluids undersaturated with respect to native $\mathrm{Au}$, increasing its scavenging potential in ore systems (Reich et al. 2005; Cook et al. 2009; Gopon et al. 2019; Pokrovski et al. 2019; Kusebauch et al. 2019).

Here, we present the microtextural occurrence and in situ chemical analyses of pyrite in the Akeshi and Kasuga highsulfidation epithermal Au deposits. Microtextural observations using scanning electron microscopy (SEM) were integrated with major, minor, and trace element analyses of pyrite performed by electron probe microanalysis (EPMA) and laser ablation inductively coupled plasma mass spectrometry (LAICP-MS). By combining these data, we contribute additional information on the hydrothermal activities that led to Au mineralization in the Nansatsu district.
Fig. 1 Location of the Akeshi and Kasuga deposits, Kagoshima, Japan

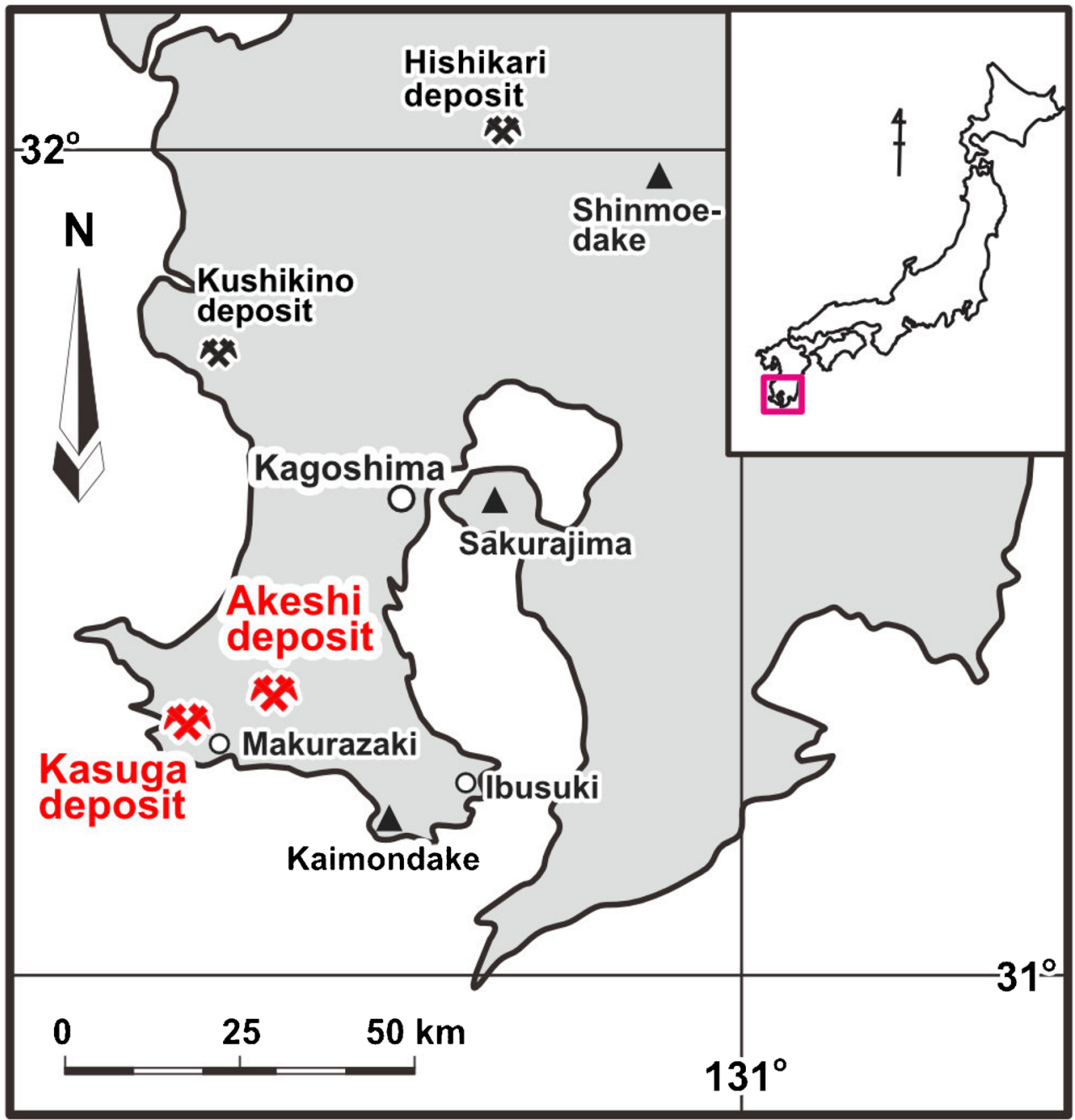




\section{Deposit geology and samples}

There are several Au-bearing silicified rocks and highsulfidation epithermal Au deposits in the southern part of the Satsuma peninsula in southern Kyushu, Japan (Nansatsu district; Fig. 2). These deposits, including Akeshi and Kasuga, are referred to as the Nansatsu-type deposits. The district is also considered to have potential for porphyry copper mineralization, although no deposit has been discovered to date (Izawa and Hayashi 2018; Watanabe et al. 2018). Alunite $\mathrm{K}-\mathrm{Ar}$ ages and paleomagnetic data from previous studies indicate an approximate age of $4 \pm 1 \mathrm{Ma}$ for the formation of the Nansatsu-type deposits (Izawa et al. 1984; Takeda et al. 2001; Watanabe 2005).

Gold mineralization in the Nansatsu district was closely associated with the eastward-shifting calc-alkaline volcanism in this region (Izawa 1992; Watanabe 2005). The Kasuga deposit is hosted by the Upper Formation of Nansatsu Group, which comprises pyroxene andesite lavas and pyroclastic rocks, whereas the Akeshi deposit is hosted by the
Nansatsu Middle Volcanics, composed of hornblende andesite lavas and pyroclastic rocks (Nakamura et al. 1994; Metal Mining Agency of Japan 1993).

Total gold production in the Akeshi deposit has reached 12.7 metric tonnes (t) since 1912 (average $\mathrm{Au}$ grade of 5.8 $\mathrm{g} / \mathrm{t} ; \mathrm{H}$. Kon per. commun. 2020) and $10.7 \mathrm{t}$ since 1910 in the Kasuga deposit (average Au grade of $2.7 \mathrm{~g} / \mathrm{t}$; K. Shinagawa per. commun. 2020). Hydrothermal activity contemporaneous with volcanism resulted in strong leaching of the volcanic host rocks by acidic fluids (Izawa 1992; Hedenquist et al. 1994b). The preferential dissolution of phenocrysts and pumice fragments produced a vuggy texture in residual quartz (Hedenquist et al. 1994b). Secondary deposition of quartz is common in vugs and veinlets, locally resulting in massive siliceous rock (Hedenquist et al. 1994b). The ore zone, with gold grades of $1 \mathrm{~g} / \mathrm{t}$ or more, is restricted to mushroom-shaped residual quartz bodies (Online Resource 1, Figs. S1 and S2) on the order of $100 \mathrm{~m}$ wide, not including the advanced argillic alteration zone around the orebody (Tokunaga 1954). Published works provided detailed descriptions of the hydro-

Fig. 2 Geological map of the Nansatsu district. Modified from the Ministry of International Trade and Industry (1985)

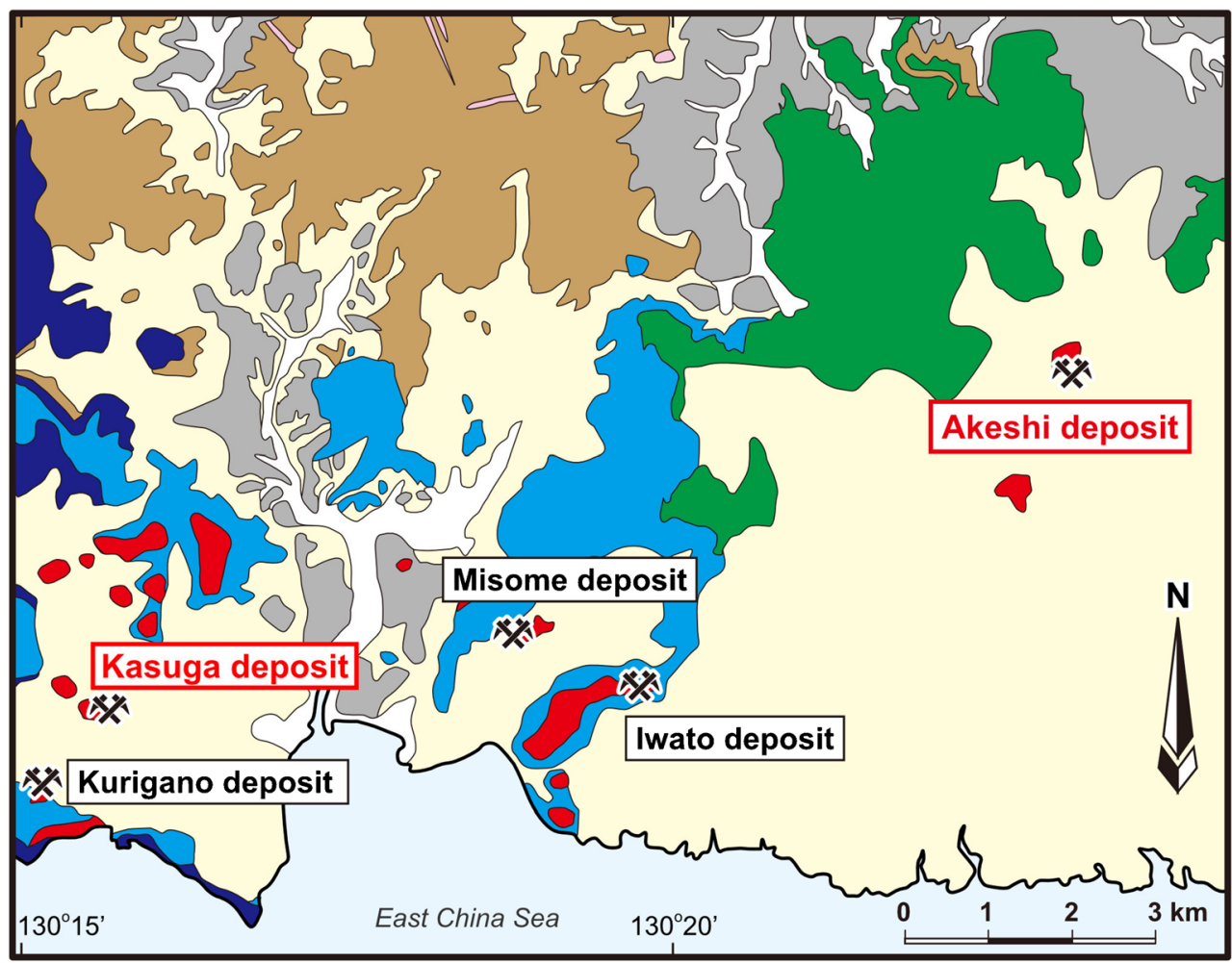

\begin{tabular}{|ll|}
\hline Quaternary alluvium & $\square$ Nansatsu Group (upper) \\
$\square$ Aira Pyroclastics & Nansatsu Group (lower) \\
$\square$ Ata Pyroclastics & $\square$ Shimanto Supergroup \\
$\square$ Nansatsu Middle Volcanics & $\square$ Porphyry \\
Silica alteration zone & High-sulfidation deposit \\
\hline
\end{tabular}


thermal alteration and gangue minerals associated with the orebody (Tokunaga 1954; Nakamura et al. 1994; Hedenquist et al. 1994b).

Limited fluid inclusion studies have been conducted in the Akeshi and Kasuga deposits due to the small size of quartz grains. All these analyses were performed on secondary quartz, formed after the initial leaching event (Hedenquist et al. 1994b; Nakamura et al. 1994). Homogenization temperatures range from 160 to $350{ }^{\circ} \mathrm{C}$, and the occurrence of vapor-rich inclusions suggests that fluids were locally trapped from boiling solutions (Takenouchi 1983; Nakamura et al. 1994; Hedenquist et al. 1994b). Generally, the salinities are low $(<1 \mathrm{wt} \%$ $\mathrm{NaCl}_{\text {eq. }}$ ) in both deposits, but higher salinities - based on the presence of daughter minerals - were reported in one sample from the Kasuga deposit (Hedenquist et al. 1994b).

The Akeshi and Kasuga ore zones typically comprise around $90 \mathrm{wt} \% \mathrm{SiO}_{2}$ as fine-grained quartz (Nakamura et al. 1994; Fig. 3). The pyrite content of the ore is reported to increase with depth, partly reflecting a decrease in postdepositional oxidation (Hedenquist et al. 1994b). Today, pyrite is ubiquitous throughout the orebody, possibly because the upper part of the orebody has already been completely mined. Alunite and native sulfur are also common in the orebody (Hedenquist et al. 1994b; Nakamura et al. 1994). According to Imai et al. (1996), the Akeshi and Kasuga ores can be classified into three types: (i) unoxidized pyrite-gold ore, (ii) unoxidized gold-copper ore, and (iii) oxidized highgrade gold ore. The unoxidized pyrite-gold ore type is the most abundant, and is composed of pyrite and rutile disseminated in fine-grained quartz. The unoxidized gold-copper ore, which comprises pyrite, enargite (in Kasuga) or luzonite (in Akeshi), covellite, scorodite, and rare native gold within a fine-grained quartz matrix, is found mainly in the upper section of the Akeshi deposit (Tokunaga 1954; Nakamura et al. 1994). The relation between these first two ore types is not well constrained. The oxidized high-grade $\mathrm{Au}$ ore is related to white quartz veinlets with native gold and rust-colored silicified rock with iron oxides (goethite, scorodite, and tripuhyte), barite, clay, and native gold (Nakamura et al. 1994; Imai et al. 1996). This ore type has the highest Au grades locally reaching $1000 \mathrm{~g} / \mathrm{t}$ or more (Imai et al. 1996) and is likely related to hypogene and/or supergene oxidation and weathering of unoxidized ore types.

Samples analyzed in this study were collected from the residual quartz orebodies in both deposits. Nine samples were obtained from three different locations in the open pit in the Akeshi deposit, and seven samples were selected from two different areas in the open pit in the Kasuga deposit (Table 1). Sampling locations, which were the active mining sites at the time of sample collection, are shown in Online Resource 1 (Figs. S1 and S2). Pyrite-rich
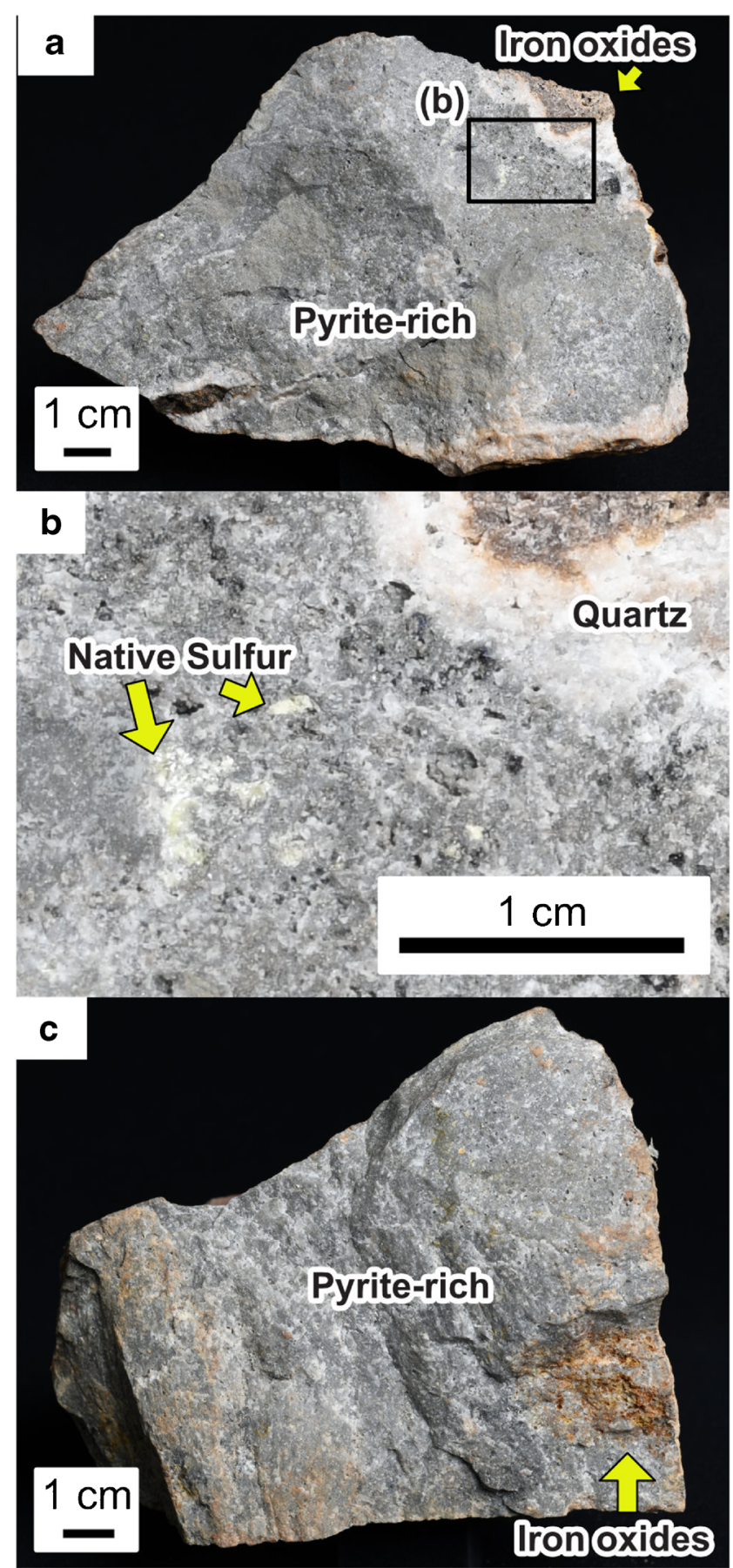

Fig. 3 Photographs of representative ore samples (residual quartz rock). a Gray-colored area is pyrite-rich, whereas the reddish zone corresponds to iron oxides. White area consists of fine-grained quartz. Akeshi deposit. b Detailed photo of a showing native sulfur in the pyrite-rich zone, finegrained quartz, and iron oxides in the upper right corner. $\mathbf{c}$ Pyrite-rich and iron oxides zone in hand sample from the Kasuga deposit

parts of each sample (Fig. 3) was selected to avoid the effect of supergene oxidation and prepared as a $2-\mathrm{cm}$ diameter polished sections. Analytical methods are reported in the Appendix. 


\section{Results}

\section{Scanning electron microscope observations}

Pyrite is the main sulfide mineral in all samples analyzed (Fig. 4, Table 1). In some samples, pyrite is spatially associated with enargite (Fig. 4a, Table 1) or rutile (Fig. 4b; Table 1), indicating that the studied samples are dominated by unoxidized pyrite-gold ore (Imai et al. 1996). Pyrite has various morphologies, from euhedral crystals (Fig. 4b, d, f) to anhedral aggregates (Fig. 4c, e). Their grain sizes also varied significantly, from a few microns to up to hundreds of microns (Fig. 4). Since pyrite grains are finely disseminated within the vuggy quartz matrix, it was not possible to discriminate pyrite associated with the initial leaching stage from pyrite formed during secondary quartz deposition. Textural features observed in eight out of 16 samples (Table 1, Fig. 5a-c, Online Resource 1 Fig. S3) indicate coupled dissolution-reprecipitation (CDR) processes (i.e., fluid-mediated mineral replacement reactions; Putnis 2009). Two common characteristics of CDR were recognized in the studied pyrite grains: (i) a porous phase that preserves the external morphology of the original grain and (ii) sharp reaction fronts between the primary grain and product phases (Fig. 5c). Some grains have multiple reaction fronts that are parallel to each other (Fig. 5a, b).
Electron probe microanalysis and X-ray maps

EPMA measurements were carried out on primary, inclusionand pore-free pyrite crystals. All EPMA analyses are reported in Online Resource 2. Cobalt and Bi data are not discussed here, because the measured concentrations may have been affected by spectral interferences from $\mathrm{Fe}$ and $\mathrm{S}$, respectively. Overall, trace element concentrations in pyrite as detected by EPMA range from a few wt $\%$ to detection limits $(\sim 100-900$ ppm). Copper, $\mathrm{Se}$, and $\mathrm{Sb}$ were detected in more than a quarter of the total analyzed points. For other elements, concentrations were below detection in more than three quarters of the analyzed points. Copper showed the greatest variation (median: $0.06 \mathrm{wt} \%$ ), ranging from a maximum concentration of $3.9 \mathrm{wt} \%$ to below the detection limit (251 ppm). Selenium also showed variation (median: $0.06 \mathrm{wt} \%$ ), ranging from $0.6 \mathrm{wt} \%$ to below the detection limit (216 ppm); higher Se concentrations were mainly attributed to two samples from the Kasuga deposits (samples KA15 and KA19). The maximum concentration of As, a key element commonly contained in high abundance in pyrite from a large variety of Au deposits, was $0.4 \mathrm{wt} \%$ (median: $0.05 \mathrm{wt} \%$ ).

WDS X-ray maps for selected elements in pyrite grains are shown in Online Resource 3. Due to the relatively high detection limits of the EPMA technique, no clear zonation was observed in the WDS maps for most elements. However, $\mathrm{Cu}$

Table 1 List of the polished section used in this study, the summary of pyrite morphology, and mineral assemblage

\begin{tabular}{|c|c|c|c|c|c|c|c|c|c|}
\hline \multirow[t]{2}{*}{ Sample name } & \multirow[t]{2}{*}{ Deposit } & \multirow[t]{2}{*}{ Orebody } & \multirow[t]{2}{*}{ Depth (mL) } & \multicolumn{3}{|l|}{ Pyrite } & \multirow[t]{2}{*}{ Rutile } & \multirow[t]{2}{*}{ Enargite } & \multirow[t]{2}{*}{$\mathrm{CDR}$} \\
\hline & & & & Euhedral & Subhedral & Anhedral & & & \\
\hline AK01 01-2 & Akeshi & $\# 1$ & 15 & + & & & & & + \\
\hline AK01-9 & Akeshi & $\# 1$ & 15 & + & + & & & & \\
\hline AK02-03 & Akeshi & $\# 2$ & 5 & + & + & +++ & & + & + \\
\hline AK02-06 & Akeshi & $\# 2$ & 5 & + & + & & & & + \\
\hline AK04-0 & Akeshi & $\# 4$ & 20 & + & & & & & \\
\hline AK04-04 & Akeshi & \#4 & 15 & +++ & + & + & + & & \\
\hline AK15112705 & Akeshi & $\# 4$ & 10 & + & & & + & & \\
\hline AK15112706 & Akeshi & $\# 4$ & 10 & +++ & & + & & & \\
\hline AK15112710 & Akeshi & $\# 4$ & 20 & + & & & & & + \\
\hline KA05 & Kasuga & Honko & 75 & & + & + & & & + \\
\hline KA08 & Kasuga & Honko & 75 & + & + & + & & & + \\
\hline KA09 & Kasuga & Honko & 75 & & + & & & & \\
\hline KA10 & Kasuga & Honko & 75 & & + & +++ & & & + \\
\hline KA15 & Kasuga & Honko & 75 & + & + & + & & & \\
\hline KA19 & Kasuga & Honko & 75 & + & + & + & & & \\
\hline KA27 & Kasuga & Honko & 130 & & + & +++ & & & + \\
\hline
\end{tabular}

$C D R$ : coupled dissolution and reprecipitation

+ : the mineral phase or the feature is observed in the sample

+++ : the mineral phase or the feature was very common in the sample 
Fig. 4 Representative backscattered electron images of pyrite (Py) disseminated in fine-grained quartz (Qz). a Anhedral pyrite grains with minor enargite (En). b Euhedral pyrite grains in a quartz matrix. Also observed is anhedral rutile (Rt). $\mathbf{c}$ Small aggregate of anhedral pyrite grains. $\mathbf{d}$ Fine and coarse euhedral pyrite grains. $\mathbf{e}$ Aggregate of small anhedral grains. $f$ Aggregate of euhedral pyrite grains. b, d, f Euhedral, relatively coarse-grained pyrites may indicate precipitation under relatively steady physicochemical conditions. $\mathbf{c}, \mathbf{e}$ Anhedral, fine-grained pyrites may represent rapid crystallization. See text for the discussion. a-d, f Akeshi deposit. e Kasuga deposit
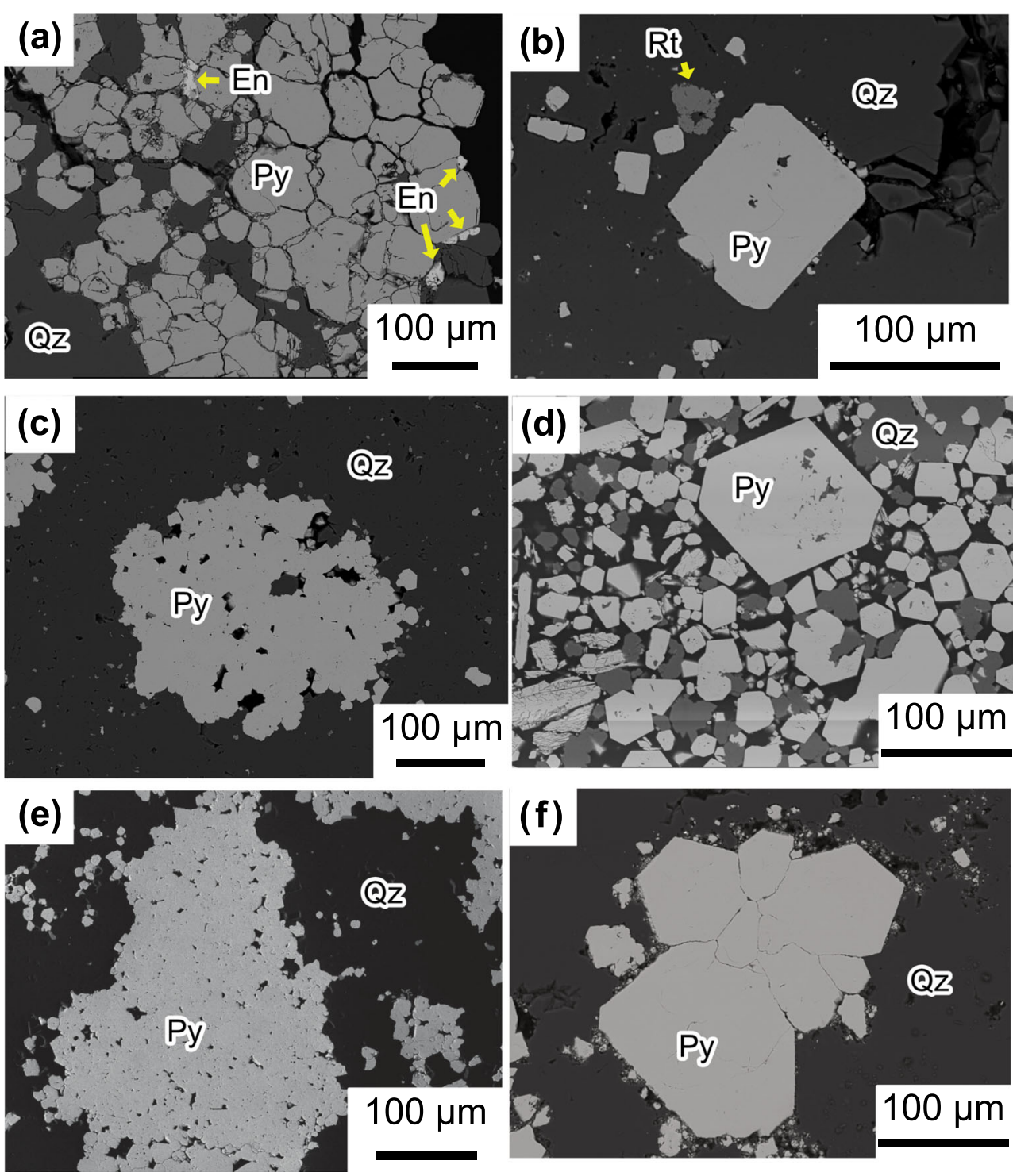

is an exception and shows sharp compositional contrasts (Figs. 6 and 7). For example, zones enriched in $\mathrm{Cu}$ were observed in 14 out of 21 EPMA pyrite maps. These include thin $(<10 \mu \mathrm{m}) \mathrm{Cu}$ - and Co-rich rims in pyrite grains (e.g., Fig. $6 \mathrm{~b}, \mathrm{~d})$, as well as $\mathrm{Cu}$-rich zones with porous, CDR-like textures (Fig. 7a, b).

\section{LA-ICP-MS trace element analysis}

We conducted LA-ICP-MS spot analyses on primary, inclusion- and pore-free pyrite crystals, as well as in pyrite aggregates and pyrite grains showing porous CDR textures. Thus, our LA-ICP-MS data represent an "efficient microsampling of small volumes" (Cook et al. 2009) of pyrite in the Akeshi and Kasuga deposits, and hence, we interpret the laser ablation signal profiles considering contributions from elements incorporated in solid solution and as (micro-/ nano-)inclusions within pyrite.

A statistical summary of LA-ICP-MS analyses is shown in Fig. 8 (results are listed in Online Resource 4). Copper, $\mathrm{Ni}, \mathrm{Pb}$, and Co were above detection in more than three quarters of the analyzed spots. Among these four elements, $\mathrm{Cu}$ showed the highest concentration (above detection median of $138.5 \mathrm{ppm}$; maximum: 7400 ppm). Arsenic, Au, Bi, Tl, Te, and Sb were detected in more than half of the spots. The maximum concentration of As (6500 ppm) was comparable to that of $\mathrm{Cu}$, but the overall concentrations were lower than $\mathrm{Cu}$ (above detection median of As concentration was $61.5 \mathrm{ppm}$ ).

Scatter diagrams of selected elements are shown in Fig. 9. Gold shows positive correlations with $\mathrm{Bi}(r=0.44)$ and $\mathrm{Cu}(r$ $=0.4$; Fig. 9a). Bismuth, Te, and Sb, on the other hand, display positive correlations between each other (Fig. 9b, d). Cobalt also shows a positive correlation with $\mathrm{Ni}(r=0.57)$. 
Fig. 5 Representative backscattered electron images of pyrites (Py) with textures indicating coupled dissolutionreprecipitation (CDR). a Pyrite grains from the Kasuga deposit with multiple layers of CDR textures. The white square is the area of elemental mapping in Fig. 7. b Pyrite from the Akeshi deposit showing a light gray rim. c A close-up image of the contact between pristine primary and altered pyrite. Akeshi deposit. For a and b, inferred reaction fronts are shown in Online Resource 1 Fig. S3
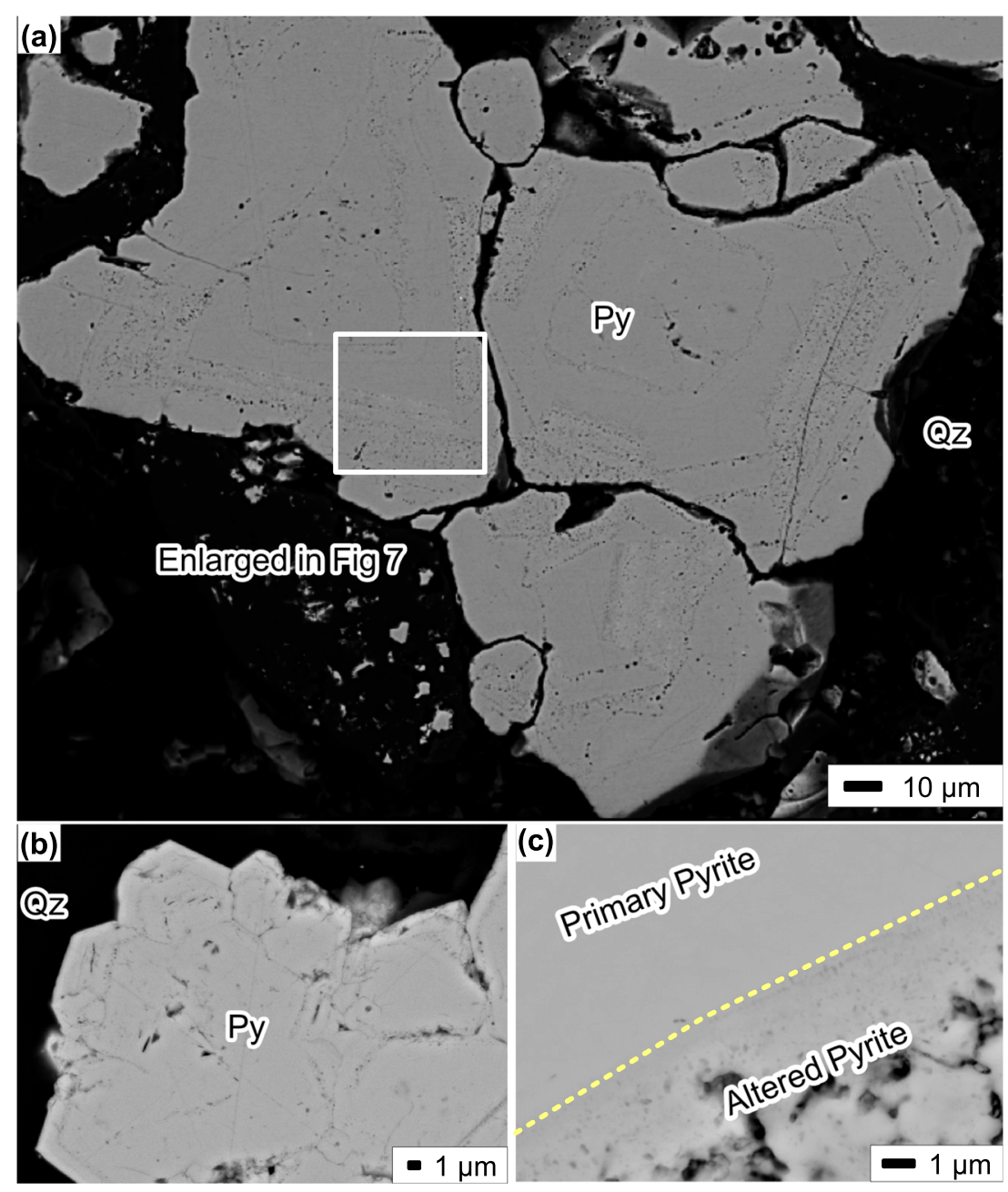

Arsenic and $\mathrm{Tl}$ did not show clear correlations with any of these elements. Correlation coefficients of $\mathrm{Cu}, \mathrm{Ni}, \mathrm{Pb}, \mathrm{Co}$, As, $\mathrm{Au}, \mathrm{Bi}, \mathrm{Tl}, \mathrm{Te}$, and $\mathrm{Sb}$ are shown in Online Resource 1 Fig. S4.

\section{Discussion}

\section{Polymetallic Au-bearing nanoparticles in pyrite}

Our LA-ICP-MS depth profiles suggest that $\mathrm{Au}$ in the analyzed pyrites is present both in solid solution and as submicron polymetallic Au-bearing inclusions (Figs. 10 and 11). Although LA-ICP-MS depth profiles alone cannot confirm the presence of metal nanoparticles, the composition of the apparent inclusions (discussed below) seems to be similar to those reported from other high-sulfidation epithermal $\mathrm{Au}$ deposits (Deditius et al. 2011).

Gold and Ag signals appear at about half of the ablation time, coinciding with increasing $\mathrm{Cu}$ and $\mathrm{Bi}$ signals (gray band in Fig. 10a, at 20-35 s; see Online Resource
1 Fig. S5 for BSE image of this analysis spot). This profile indicates that $\mathrm{Au}$ is distributed heterogeneously in pyrite, probably forming clusters of $\mathrm{Au}-\mathrm{Ag}-\mathrm{Bi}-\mathrm{Cu}$-bearing nanoparticles.

Profiles of $\mathrm{Au}$ and Te (Fig. 10b) display matching sharp peaks (gray bands). For example, at $\sim 35 \mathrm{~s}$, signal peaks of $\mathrm{Au}$ and Te correspond to peaks in the $\mathrm{Cu}$ and $\mathrm{Sb}$ profile. These observations suggest the presence of $\mathrm{Au}-\mathrm{Te}$ and $\mathrm{Au}-\mathrm{Te}-\mathrm{Sb}-\mathrm{Cu}$ nanoparticles at the analyzed spot. These nanoparticles might be related to CDR processes (Cook et al. 2009; Deditius et al. 2011; Tooth et al. 2011), since several CDR-like textures are observed near this spot (See Online Resource 1 Fig. S6 for BSE image of this analysis spot).

The presence of $\mathrm{Pb}$ and $\mathrm{Sb}-\mathrm{Au}$ nanoparticles is inferred based on similar patterns (gray bands; Fig. 11b). These nanoparticles may also have been formed via CDR processes, although there is no conclusive evidence-for instance, preservation of the external morphology of the parent phase- to support our suggestion that porous zones in the corresponding spot (Fig. 11a) were actually formed via CDR processes. 
Fig. 6 a, c Back-scattered electron images of representative pyrite grains from the Akeshi deposit. b, d Corresponding wavelength-dispersive spectrometry X-ray elemental mapping of $\mathrm{Cu}$ in pyrite $(\mathrm{Py})$ showing the $\mathrm{Cu}-$ rich rim
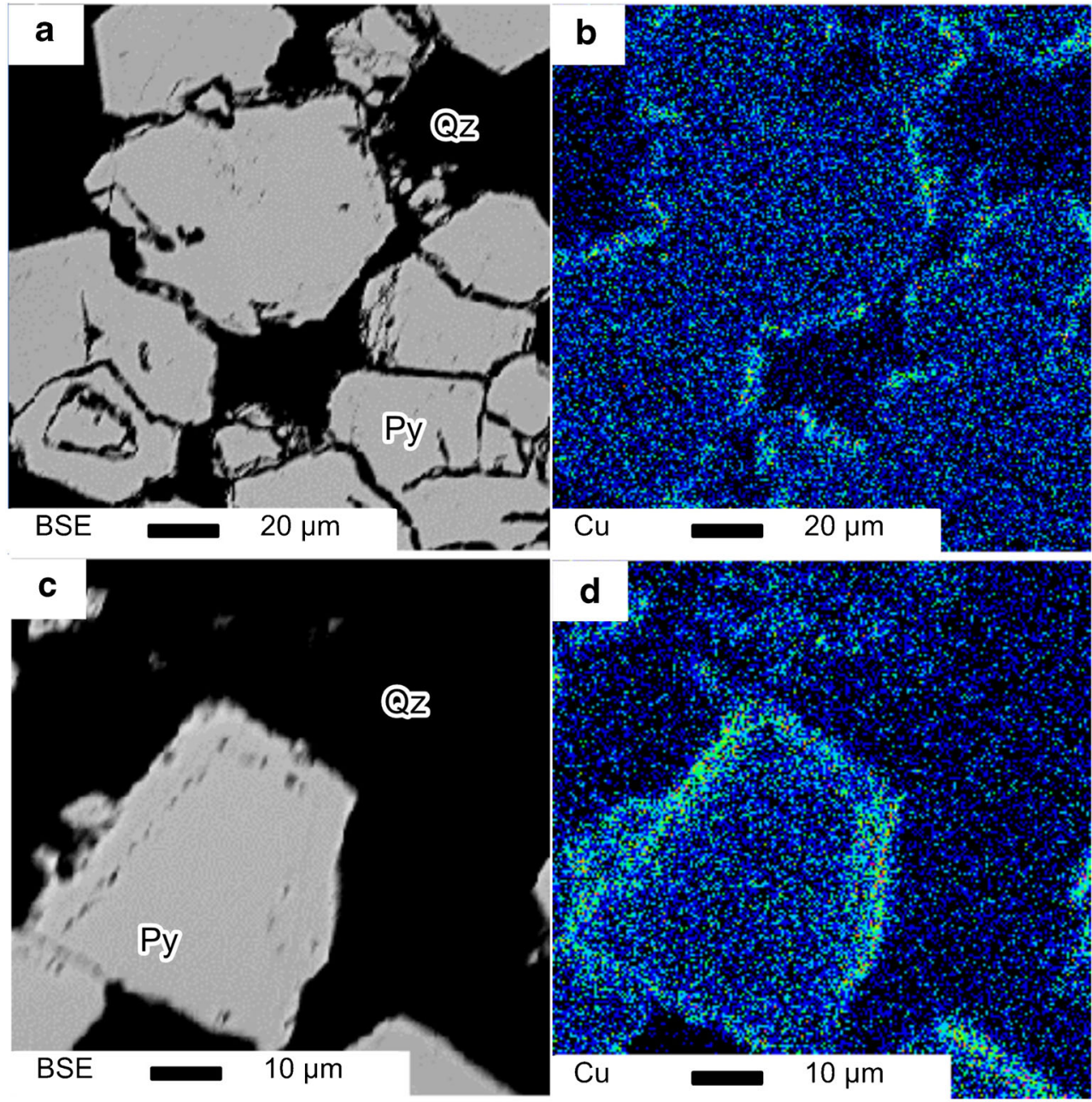

High
Low

\section{Au-As relation in pyrite}

Gold and As in pyrite commonly show a positive correlation in many hydrothermal Au deposits (Reich et al. 2005; Deditius et al. 2008, 2014; Morishita et al. 2018), which has led previous studies to propose a key role of As to facilitate $\mathrm{Au}$ incorporation into the pyrite structure (e.g., Kusebauch et al. 2019; Pokrovski et al. 2019). The Au-As correlation in pyrite was also examined by Morishita et al. (2019) for the Akeshi and Kasuga deposits. Based on 21 secondary ion mass spectrometry (SIMS) analyses, they concluded that the $\mathrm{Au}-\mathrm{As}$ relationship is not clear.

Our significantly larger dataset (617 LA-ICP-MS analyses) complements a previous study of the Akeshi and Kasuga deposits (Morishita et al. 2019), allowing a broader evaluation of the $\mathrm{Au}-\mathrm{As}$ relation. Our LA-ICP-MS data for $\mathrm{Au}$ and As in pyrite (Fig. 12) are consistent with concentrations reported in previous SIMS analyses (gray area in Fig. 12, from Morishita et al. 2019). Gold and As do not show a clear correlation, which may be due to the variable forms of incorporation of these two elements in the studied pyrite grains. Gold incorporation has been thought to be enhanced by $\mathrm{As}^{1-}$, which substitutes for S in pyrite (e.g., Fleet and Mumin 1997). Recently, more oxidized forms of As in pyrite, such as $\mathrm{As}^{3+}$, which substitutes for $\mathrm{Fe}$ (Deditius et al. 2008), and $\mathrm{As}^{0}$, which exists as "liquid-like" inclusions (Deditius et al. 2009b), have also been reported in pyrite from other high-sulfidation deposits (e.g., Pueblo Viejo, Dominican Republic). $\mathrm{As}^{3+}$ is reported to correlate with $\mathrm{Au}$ in the Yanacocha high-sulfidation epithermal gold deposit in Peru (Deditius et al. 2008), but it remains unclear whether this correlation truly reflects the ability of $\mathrm{As}^{3+}$ in pyrite to enhance $\mathrm{Au}$ incorporation (i.e., higher pyrite-fluid partition coefficient for $\mathrm{Au}$ ). Instead, it may simply reflect the composition of the mineralizing fluid and/or the depositional environment (e.g., pressure, temperature) as suggested by several other studies (e.g., Reich and Becker 2006; Deditius et al. 2009a; Reich et al. 2013; Tardani et al. 2017; Román et al. 2019; Herazo et al. 2021). Since we do not have 

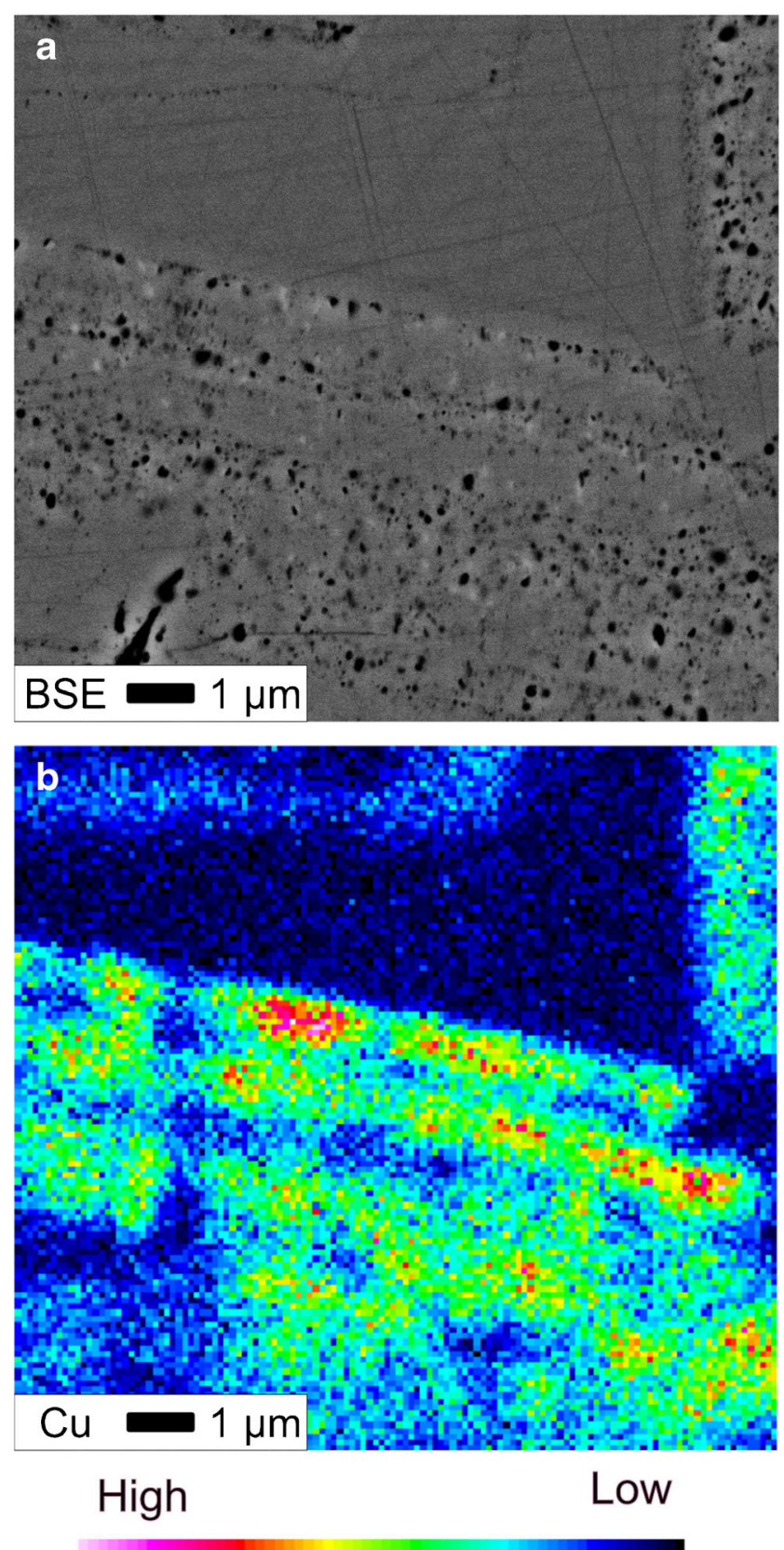

Fig. 7 a Detailed back-scattered electron image of a coupled dissolutionreprecipitation rim. The area corresponds to the white rectangle in Fig. 5a. b Corresponding wavelength-dispersive spectrometry X-ray elemental mapping of $\mathrm{Cu}$

clear evidence for As speciation in pyrite in the studied deposits, we consider it difficult to evaluate the role of $\mathrm{As}$ in $\mathrm{Au}$ uptake in the Akeshi and the Kasuga deposits. Future spectroscopic studies (e.g., synchrotron XANES and EXFAS) should provide further evidence on As oxidation state(s) and incorporation into pyrite (e.g., Simon et al. 1999a; Savage et al. 2000; Manceau et al. 2020) and its influence on $\mathrm{Au}$ enrichment.

\section{Cu enrichment events recorded in pyrite}

\section{$\mathrm{Cu}$ as an indicator of changes in ore-forming environments}

In the Akeshi and Kasuga pyrites, the $\mathrm{Cu}$ content shows a larger variation than other elements. In addition, $\mathrm{Au}$ and $\mathrm{Bi}$ contents show positive correlations with $\mathrm{Cu}$ content (Fig. 9). Here, we discuss the $\mathrm{Cu}$ concentration and distribution in pyrite and evaluate its use to track changes in elemental supply and/or physico-chemical conditions during the genesis of these deposits.

Copper negatively correlates with the $\mathrm{Fe}$ content in pyrite (Fig. 13; $r=-0.52$ ). This negative correlation between $\mathrm{Fe}$ and $\mathrm{Cu}$ is a common feature between the Akeshi (orange triangles) and Kasuga (blue circles) deposits. Since inclusion-free pyrite grains were selected for microprobe analyses, the effect of nanoparticles, especially those related to CDR and porous textures, is small. Therefore, simple substitution of $\mathrm{Fe}^{2+}$ for $\mathrm{Cu}^{2+}$ in pyrite is likely to be the major mechanism for $\mathrm{Cu}$ incorporation into the Akeshi and Kasuga pyrite, as has been reported in several hydrothermal deposits (e.g., Pacevski et al. 2008; Reich et al. 2013). However, the negative correlation between $\mathrm{Fe}$ and $\mathrm{Cu}$ is not necessarily conclusive evidence for the elemental substitution process, as it is common for $\mathrm{Cu}$ to occur as both solid solution and micro- to nano-sized inclusions (Pacevski et al. 2008; Reich et al. 2013), and hence, their influence cannot be disregarded.

Previous studies have suggested that the trace element content in the pyrite structure reflects the trace element composition of the pyrite-forming fluid (Deditius et al. 2009a; Reich et al. 2013; Tardani et al. 2017). Based on these findings, the $\mathrm{Cu}$ content in the Akeshi and Kasuga pyrites may reflect changes in the $\mathrm{Cu}$ content of the oreforming fluid. High-temperature fluids may be responsible for the $\mathrm{Cu}$ enrichment, considering that the solubility of $\mathrm{Cu}$ in Cl-bearing hydrothermal fluids is enhanced at higher fluid temperature (Liu and McPhail 2005; Kouzmanov and Pokrovski 2012).

\section{Rapid crystallization of Cu-rich pyrite}

The trace element composition of pyrite can be influenced by its growth rate, in addition to the composition of the pyriteforming fluid (e.g., Chouinard et al. 2005a). The fact that relatively large euhedral grains (Fig. 4b, d, f) and aggregates of small $(<25 \mu \mathrm{m}$; smaller than our LA-ICP-MS spot $)$ anhedral pyrite grains (Fig. 4c, e) both exist in the Akeshi and Kasuga deposits suggests that the pyrite growth rate fluctuated during ore formation. Among these morphologies, the small grain aggregates are suggestive of rapid pyrite crystallization from the hydrothermal fluid (Huston et al. 1995; Simon et al. 1999b; Román et al. 2019). All the aggregates analyzed 
Fig. 8 Graphical summary of LA-ICP-MS spot analyses $(n=$ 617) of pyrite from the Akeshi and Kasuga deposits. Each boxplot illustrates the minimum, median, and maximum concentrations. The number of analyses above detection limit for each element is labeled above each box

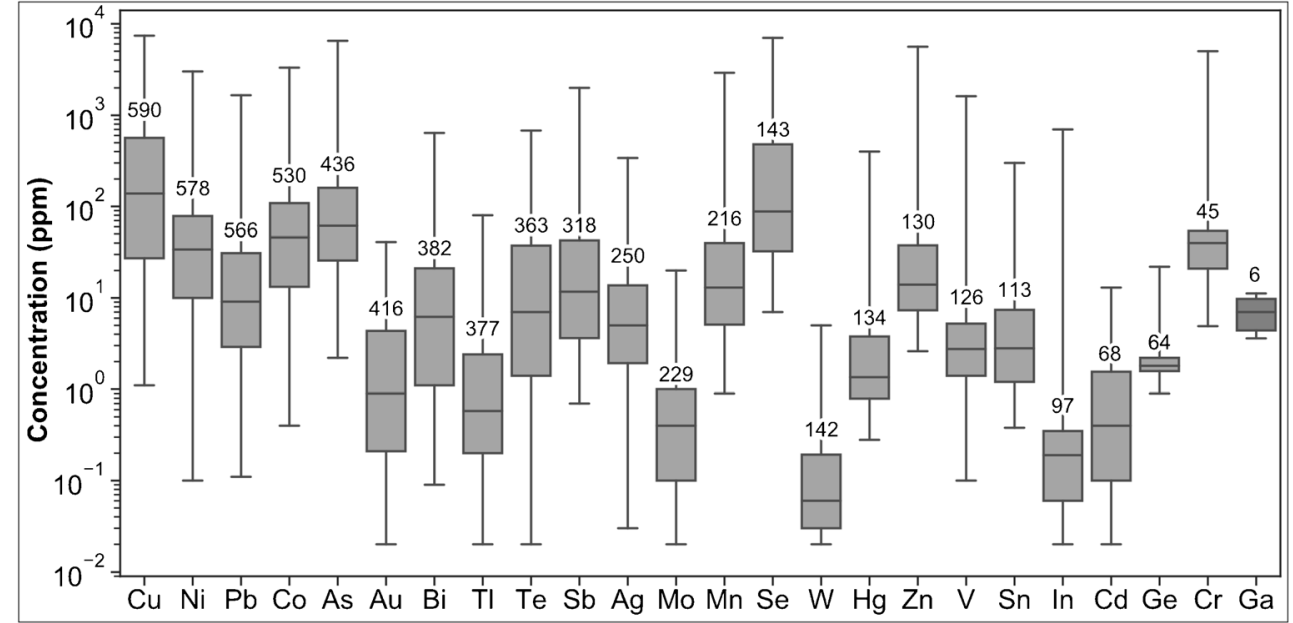

in this study ( $n=55$ ) show higher $\mathrm{Cu}$ concentrations (median, $1900 \mathrm{ppm}$ ) than the other pyrite types (Fig. 14). Moreover, the range of $\mathrm{Cu}$ contents in the aggregates is two orders of magnitude less than in all other pyrite types analyzed herein, which is not observed for other elements (Fig. 14). Therefore, the processes that formed the pyrite aggregates (i.e., rapid crystallization) in the Akeshi and Kasuga deposits likely triggered efficient $\mathrm{Cu}$ precipitation.
Fig. 9 Scatter diagrams of a $\mathrm{Cu}$ vs. $\mathrm{Au}, \mathbf{b} \mathrm{Sb}$ vs. $\mathrm{Bi}, \mathbf{c} \mathrm{Cu}$ vs. $\mathrm{Bi}$, and $\mathbf{d} \mathrm{Sb}$ vs. Te for pyrite from the Akeshi and Kasuga deposits. See text for the discussion
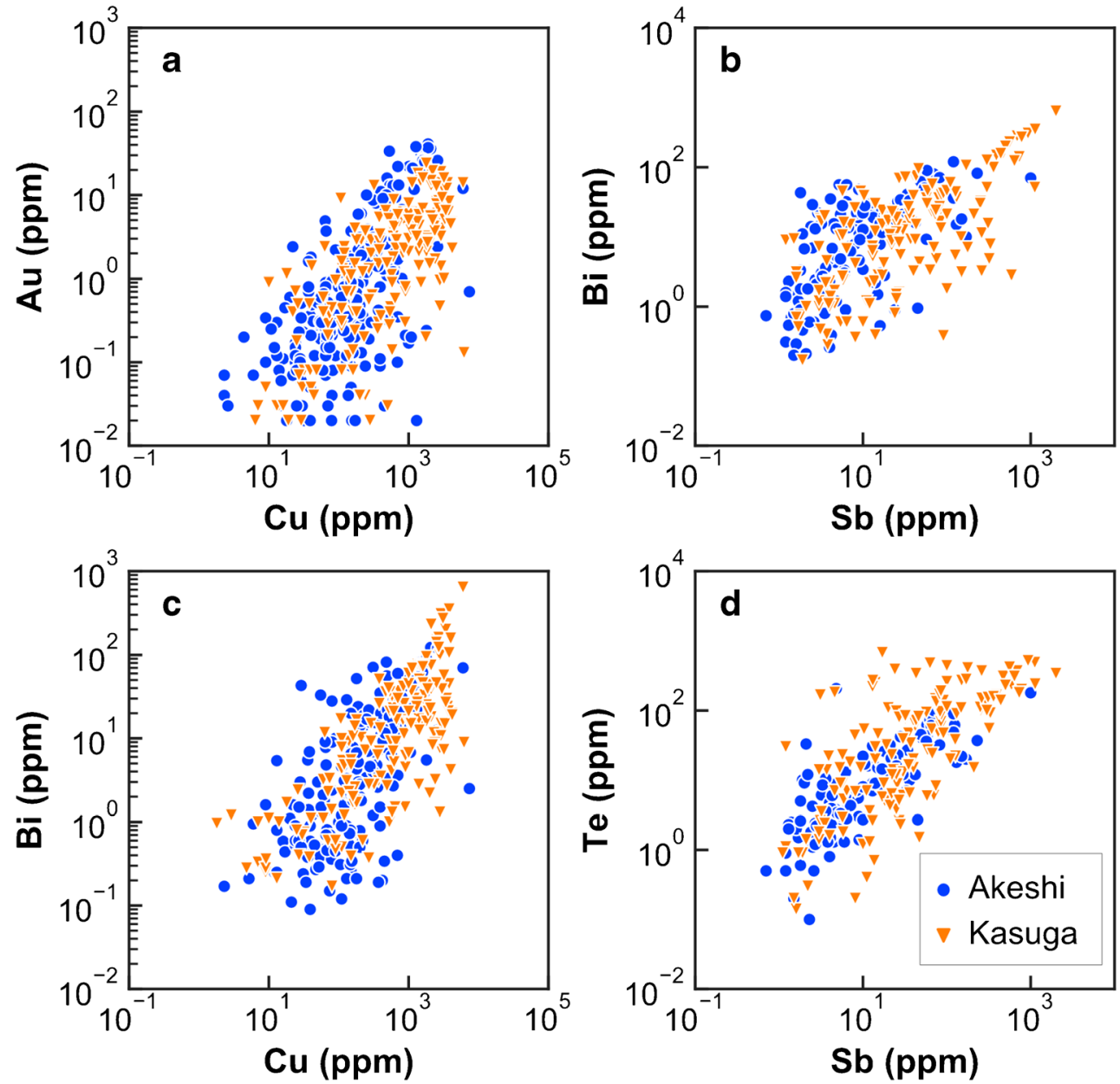

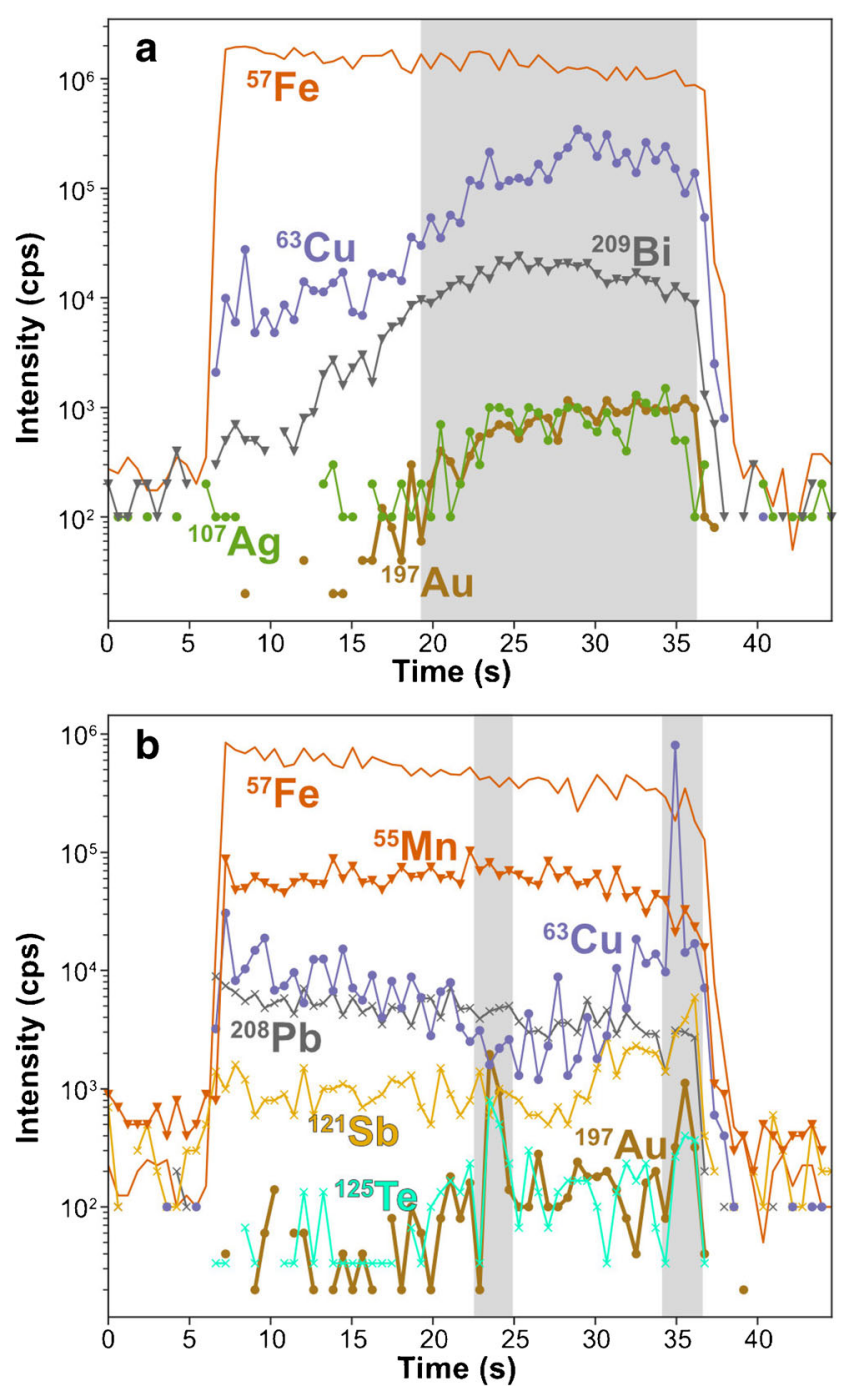

Fig. 10 Representative depth-concentration profiles (time versus intensity) of selected isotopes obtained by LA-ICP-MS analysis of pyrite from the Kasuga deposit. The profiles correspond to the spots shown in the light blue circles in a Online Resource 1 Fig. S5 and b Online Resource 1 Fig. S6a. a Note that the signal intensity of $\mathrm{Au}$ and $\mathrm{Ag}$ increases at $\sim 20 \mathrm{~s}$ coupled to an increase in the $\mathrm{Cu}$ and $\mathrm{Bi}$ signals, indicating a heterogeneous distribution of these elements. b The spiky signal of Au corresponds with $\mathrm{Te}$ (in the left gray zone) and $\mathrm{Sb}, \mathrm{Cu}$, and $\mathrm{Te}$ (in the right gray zone), indicating the presence of $\mathrm{Au}-\mathrm{Te}$ and $\mathrm{Au}-\mathrm{Te}-\mathrm{Sb}-\mathrm{Cu}$ nanoparticles

In addition to $\mathrm{Cu}$, the pyrite aggregates contain higher concentrations of $\mathrm{Pb}, \mathrm{Sb}, \mathrm{Te}, \mathrm{Bi}$, and $\mathrm{Au}$ than other pyrite types (Fig. 14). The 1st quartile elemental contents of pyrite aggregates are higher than the 3 rd quartile elemental contents of other pyrite types. This may reflect abundant micro- to nano-sized sulfosalt inclusions and polymetallic nanoparticles in pyrite (e.g., Deditius et al. 2011; Ciobanu et al. 2012), probably due to supersaturation of the fluid with respect to these elements. In contrast, the concentration of $\mathrm{Co}, \mathrm{Ni}, \mathrm{As}$, and $\mathrm{Tl}$ in all pyrites are similar (Fig. 14).
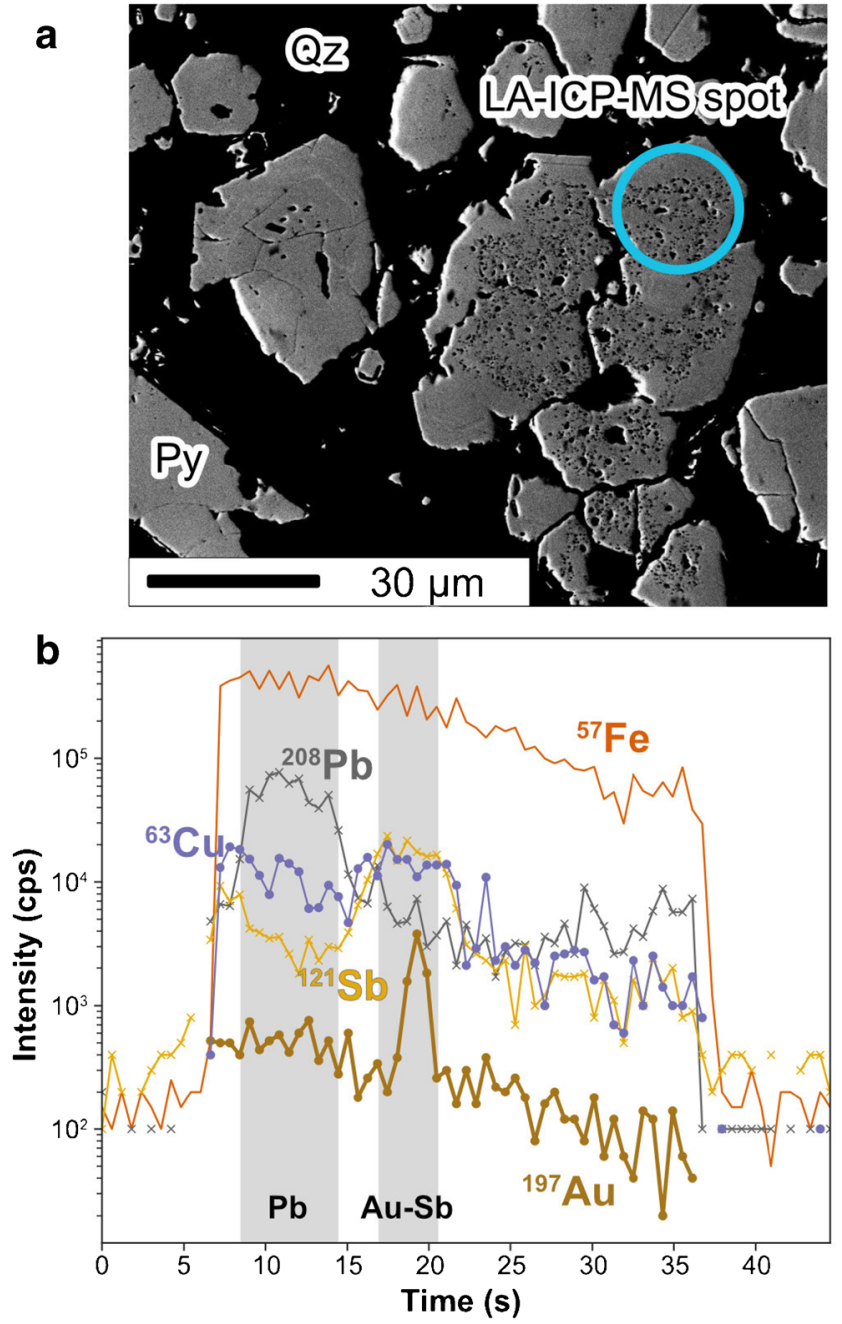

Fig. 11 a Back-scattered electron image of porous pyrites (Py) from the Akeshi deposit presumably created via coupled dissolutionreprecipitation. The light blue circle denotes the location of the LAICP-MS analysis. b LA-ICP-MS depth-concentration profiles (time versus intensity) of selected isotopes in the area in a. The spiky peaks of $\mathrm{Pb}$, $\mathrm{Sb}$, and $\mathrm{Au}$ indicate the presence of micro- and/or nano-inclusions or aggregates of particles

\section{Cu-rich overgrowth in pyrite}

Sector and concentric zoning in pyrite can be related to two different types of control on trace element incorporation into pyrite (Chouinard et al. 2005a), either stereochemical influence of the crystal surface structure on the incorporation of trace elements, or concentric zoning that is believed to reflect temporal variation of the pyrite-forming fluid condition (e.g., temperature and/or fluid composition) (Chouinard et al. 2005a; Deditius et al. 2009a; Reich et al. 2013; Tardani et al. 2017).

The WDS X-ray elemental maps (Fig. 6) illustrate pyrite with $\mathrm{Cu}$-rich overgrowths. Concentric micrometer-wide zones enriched in $\mathrm{Cu}$ were identified in some pyrite grains (Fig. $6 \mathrm{~b}, \mathrm{~d})$. Such sharp transition from the trace element-poor core 


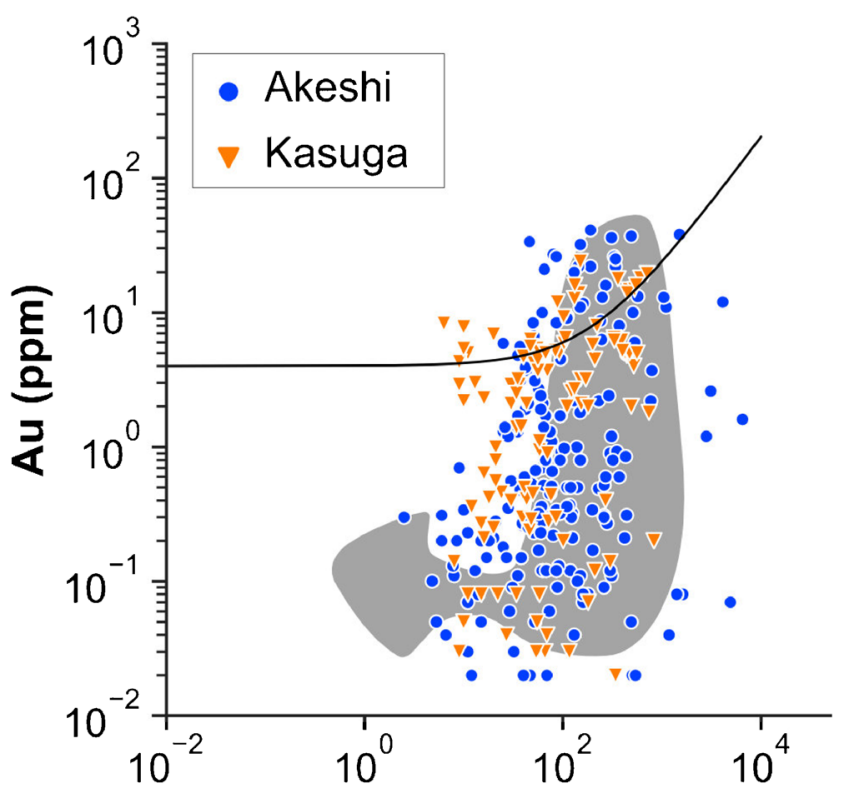

As (ppm)

Fig. 12 Scatter diagram of As versus $\mathrm{Au}$ content in pyrites from the Akeshi and Kasuga deposits. Black curve represents the solubility limit of $\mathrm{Au}$ as a function of As (Reich et al. 2005). Gray-shaded area is the range of $\mathrm{Au}$ and As concentration in pyrite from the Akeshi and Kasuga deposits reported by Morishita et al. (2019).

to micron-scale, $\mathrm{Cu}$-rich rim in pyrite from $\mathrm{Au}$ deposits in epithermal environments has been suggested to form as a consequence of rapid changes in the composition and/or physicochemical condition of the pyrite-forming fluid (Deditius et al. 2009a; Peterson and Mavrogenes 2014; Sanchez-Alfaro et al.

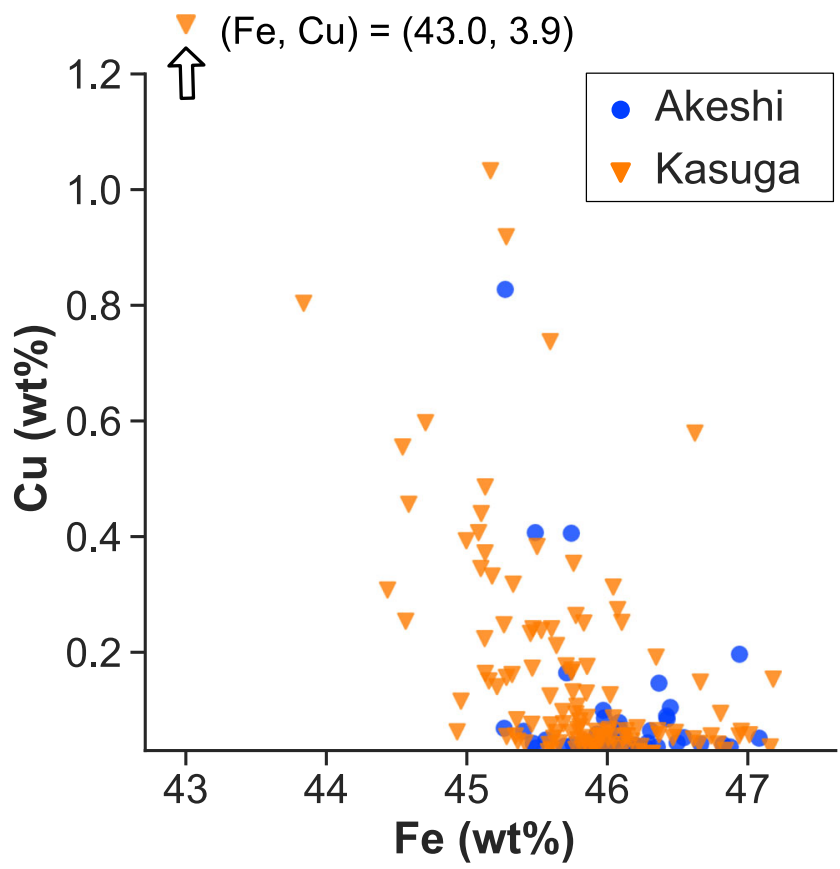

Fig. 13 Scatter diagram of $\mathrm{Fe}$ versus $\mathrm{Cu}$ content (wt\%) in pyrites of the Akeshi and Kasuga deposits. Data from electron probe microanalysis (EPMA)
2016; Tardani et al. 2017; Wu et al. 2019b). Hence, it seems reasonable to assume that the $\mathrm{Cu}$ content of the ore-forming fluid in the Akeshi and Kasuga deposits experienced a relatively sudden increase, which we refer to as a $\mathrm{Cu}$ enrichment event. Since $\mathrm{Au}$ in pyrite positively correlates with $\mathrm{Cu}$ (Fig. 9a), the $\mathrm{Cu}$ enrichment event is likely related to at least a portion of the Au mineralization in the Akeshi and Kasuga deposits. In addition, the rapid crystallization of $\mathrm{Cu}$-rich pyrite suggested by the anhedral aggregates also seems to be closely associated with the $\mathrm{Cu}$ enrichment event.

\section{Replacement of primary pyrite by Cu-rich pyrite}

The porous zones in some pyrite grains probably formed via CDR (Fig. 7a), as they usually match the Cu-rich zones identified in the EPMA elemental maps (Fig. 7b). This suggests that primary (early) pyrite was replaced by $\mathrm{Cu}$-rich pyrite via CDR. However, a caveat is that our WDS X-ray maps yield relative concentrations, not absolute values. In addition, we were not able to measure the actual composition of the porous zones because most were not smooth enough for microprobe analysis; also, other mineral inclusions or nanoparticles may also be present (e.g., the extremely Cu-rich area in Fig. 6b).

In the Akeshi and Kasuga deposits, multiple CDR textures can be recognized in a single pyrite grain of several hundred microns. This observation suggests repetitive $\mathrm{Cu}$ enrichment events in a relatively short period. Although no detailed data regarding the timescale of pyrite $\mathrm{CDR}$ are available, previous experimental studies showed that CDR could be a relatively fast process, on the order of seconds to minutes (Renard et al. 2019) or days to weeks (Putnis 2009).

\section{Implications for the mineralization processes}

\section{Possible cause of $\mathrm{Cu}$ enrichment events}

According to Deditius et al. (2009a), abrupt and intermittent changes in the composition of the pyrite-forming fluid, the $\mathrm{Cu}$ enrichment event, are unlikely to occur by wall-rock reaction or mineral deposition; rather, such changes are more likely to occur when a (magmatic) fluid separates into two different fluids or by mixing with another fluid. Within this framework, one possible scenario is intermittent introduction of magmatic fluids into the brittle, lower-pressured domain, where meteoric water circulates at hydrostatic pressure (Fournier 1999). The fluid injection itself can also promote hydraulic fracturing and brecciation in the brittle domain and reduce fluid pressure and temperature, which further enhances phase separation and/or fluid mixing between magmatic and meteoric fluid (Sillitoe 1985; Fournier 1999). Hence, steep pressure and temperature gradients are required to explain the $\mathrm{Cu}$ enrichment events. Although direct evidence of magmatic fluid is lacking, most previous studies agree that magmatic fluids supply a major 
Fig. 14 Boxplots showing the compositional difference of pyrite aggregates (indicating rapid crystallization) and other pyrites in this study. For $\mathrm{Cu}, \mathrm{Pb}, \mathrm{Sb}, \mathrm{Te}$, $\mathrm{Bi}$, and $\mathrm{Au}$, concentrations are much higher in "Aggregates." Horizontal lines in the boxes denote the median, and the bottom and top of each box denote the 1 st and 3 rd quartiles, respectively. The number of analyses above detection limit for each element is labeled below each box

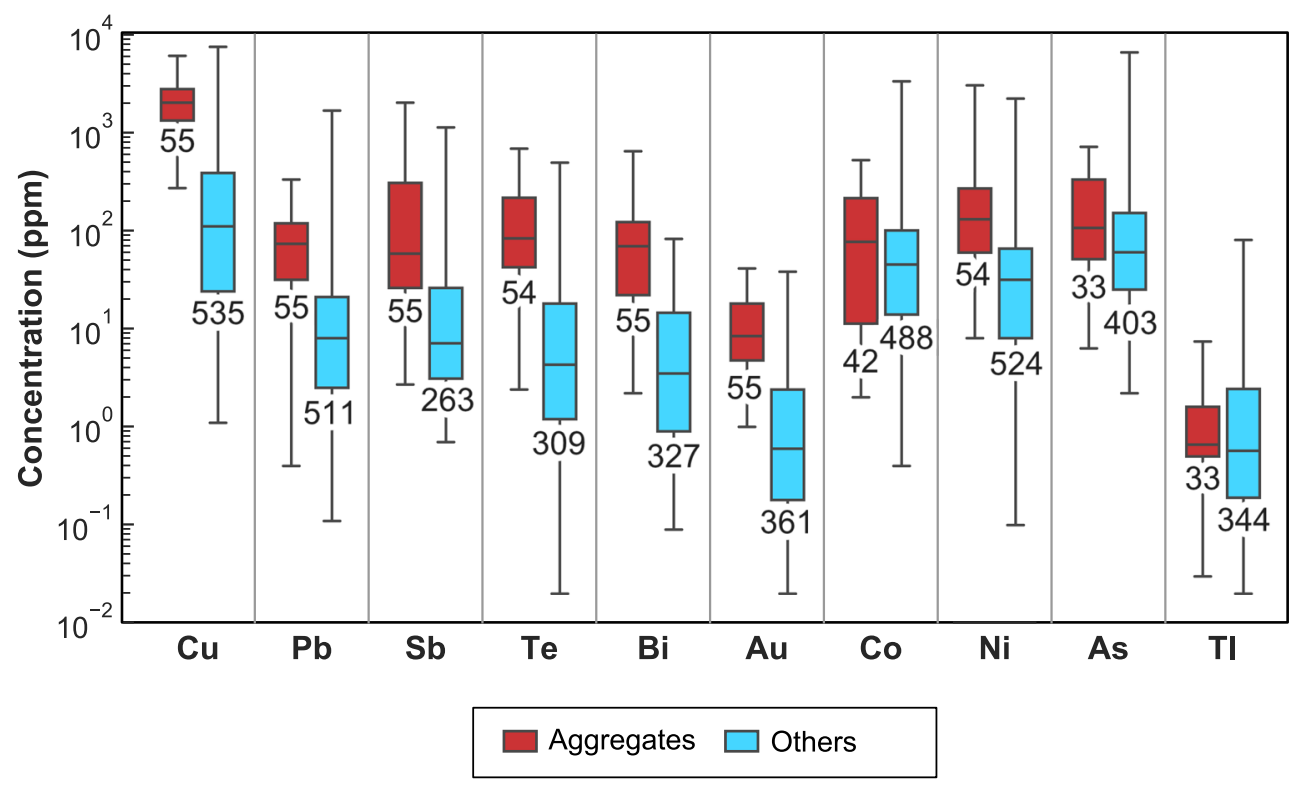

portion of the $\mathrm{Au}$ and $\mathrm{Cu}$ in high-sulfidation deposits (Vennemann et al. 1993; Arribas 1995; Heinrich 2005). This interpretation may also be consistent with findings in other hydrothermal Au deposits that pressure-driven, episodic hydrothermal fluid movements in brittle rheological zones are recorded in pyrite grains, sometimes bearing CDR textures (Peterson and Mavrogenes 2014; Rottier et al. 2016; Sanchez-Alfaro et al. 2016; Wu et al. 2019a).

\section{Role of pyrite in mineralization}

Deposition of $\mathrm{Au}$ in epithermal deposits is commonly regarded as a consequence of $\mathrm{H}_{2} \mathrm{~S}$ removal, destabilization of $\mathrm{Au}$ hydrosulfide complexes (the dominant $\mathrm{Au}$ species in epithermal environments), and supersaturation of the fluid with respect to $\mathrm{Au}^{0}$ or other $\mathrm{Au}$ minerals (e.g., Drummond and Ohmoto 1985; Krupp and Seward 1987; Stoffregen 1987; Spycher and Reed 1989). Major processes that remove $\mathrm{H}_{2} \mathrm{~S}$ in epithermal environments include boiling, fluid oxidation, and sulfide precipitation (Pokrovski et al. 2014 and references therein).

Indeed, the $\mathrm{Cu}$ enrichment events in the Akeshi and Kasuga deposits are likely to have caused the rapid crystallization of pyrite, consuming some $\mathrm{H}_{2} \mathrm{~S}$ from the fluid. However, these events do not appear to have always resulted in the immediate supersaturation of $\mathrm{Au}$ in the fluid; this is evidenced by the fact that no pyrite grain in this study, including the rapidly crystallized aggregates, coexists with discrete or visible Au minerals. In addition, more than half of our LAICP-MS analyses detected Au in pyrite. Considering that pyrite can precipitate over a wide range of temperatures and physico-chemical conditions (e.g., Reich et al. 2013), it is plausible to consider a continuous formation of Au-bearing pyrite after the $\mathrm{Cu}$ enrichment events in the Akeshi and
Kasuga deposits. Our findings indicate, at least qualitatively, that the hydrothermal fluid was largely undersaturated (e.g., Simmons et al. 2016 and references therein) with respect to native $\mathrm{Au}$ for a considerable period during the mineralization process.

When the fluid is undersaturated with respect to $\mathrm{Au}$, processes operating at the mineral surfaces can play an important role in Au mineralization (e.g., Kusebauch et al. 2019); the Au hydrosulfide complexes in the fluid can be adsorbed onto the growing pyrite surface, and consequently, Au can be incorporated in pyrite either as solid solution or nanoparticles (Widler and Seward 2002; Reich et al. 2005; Pokrovski et al. 2019). Adsorption on growing pyrite surfaces, a potentially effective mechanism for scavenging Au from a relatively Au-poor flu$\mathrm{id}$, is also proposed to have played a key role in mineralization in other high-sulfidation deposits where pyrite is the main host of Au (Chouinard et al. 2005b; King et al. 2014). Therefore, we suggest that the same mechanism may also have contributed to Au mineralization in the Akeshi and Kasuga deposits. This is consistent with the Au-As plot (Fig. 12) where $80 \%$ of the data points plot below the empirical Au solubility line defined by Reich et al. (2005). This indicates that most of the $\mathrm{Au}$ in pyrite occurs in solid solution, probably as a consequence of adsorption and incorporation from solutions undersaturated with respect to native $\mathrm{Au}$ (or other $\mathrm{Au}$-bearing mineral species).

\section{Conclusions}

This study combined SEM, EPMA, and LA-ICP-MS analyses to unravel the microtextural characteristics and in situ chemical composition of pyrite, a main Au-bearing phase in the Akeshi and Kasuga high-sulfidation deposits in Kagoshima, 
Japan. Overall, pyrite from the Akeshi and Kasuga deposits shows various morphologies, from euhedral crystals to anhedral aggregates of small pyrite grains; the latter indicating rapid crystallization from a hydrothermal fluid. In addition, multiple coupled dissolution-reprecipitation (CDR) textures are commonly recorded within single pyrite grains a few hundred micrometers in diameter. The CDR textures indicate the replacement of primary pyrite by $\mathrm{Cu}$-rich pyrite.

Several trace elements including $\mathrm{As}, \mathrm{Au}, \mathrm{Bi}, \mathrm{Co}, \mathrm{Cu}, \mathrm{Ni}$, $\mathrm{Pb}, \mathrm{Sb}, \mathrm{Te}$, and $\mathrm{Tl}$ were detected in more than half of the LAICP-MS analyses of all pyrite types. Pyrite aggregates formed by rapid crystallization have higher $\mathrm{Cu}, \mathrm{Au}, \mathrm{Pb}, \mathrm{Sb}, \mathrm{Te}$, and $\mathrm{Bi}$ concentrations than large, euhedral pyrite grains, whereas $\mathrm{Cu}$ rich overgrowths likely reflect rapid changes in the pyriteforming fluid composition. In general, the $\mathrm{Cu}$ content in pyrite has a large variation compared to other elements and positively correlates with the Au content in pyrite. Most Au in pyrite is likely to exist as solid solution, whereas Au-bearing, polymetallic micron- to nanometer-sized inclusions may be present in some portions of pyrite grains. Gold and As in pyrite of the Akeshi and Kasuga deposits do not show a clear correlation, presumably reflecting multiple valence states of these elements.

Finally, we suggest that episodic input of metal-rich fluid, likely magmatic in origin, may be recorded in pyrite grains as sharp changes in trace element composition. Gold adsorption onto growing pyrite surfaces may also have played a key role in mineralization by scavenging Au from a relatively Au-poor fluid.

\section{Appendix: Analytical methods}

Microtextural observations of the pyrite-bearing samples were carried out by using a JEOL JXA-8500F scanning electron microscope (SEM) at the Japan Agency for Marine-Earth Science and Technology (JAMSTEC) and a FEI Quanta 250 SEM at the Andean Geothermal Center of Excellence (CEGA) in the Department of Geology, University of Chile, Santiago.

Electron probe microanalysis (EPMA) of pyrite grains (362 spot analyses in total) was performed at the JAMSTEC using a field-emission JEOL JXA-8500F instrument. The beam energy was $20 \mathrm{keV}$, the beam current was $12 \mathrm{nA}$, and the beam size was 0.1 to $3 \mu \mathrm{m}$. Elements were detected using the following analyzing crystals: $\mathrm{LiF}$ for $\mathrm{Mn} \mathrm{K} \alpha, \mathrm{Fe} \mathrm{K} \alpha, \mathrm{Cu} \mathrm{K} \alpha, \mathrm{Zn}$ $\mathrm{K} \alpha$; LiFH for $\mathrm{Co} \mathrm{K} \alpha$, Ni K $\alpha$; PETJ for $\mathrm{S} \mathrm{K} \alpha, \mathrm{Pb} \mathrm{M} \alpha$, Sb L $\alpha$; PETH for Bi $M \alpha, \operatorname{Ag} L \alpha$; and TAP for As $L \alpha$, Se $L \alpha$. The standards used (Astimex MINM-25-53 and METM-25-44) included natural and synthetic sulfides, arsenides, tellurides, selenides, and native metals. Wavelength-dispersive spectrometry (WDS) X-ray maps were also acquired, with beam energy $20 \mathrm{keV}$, beam current $50 \mathrm{nA}$, and beam size 0.1 to 3 $\mu \mathrm{m}$.

LA-ICP-MS spot analyses of selected pyrite grains (617 points in total) were conducted using a $193 \mathrm{~nm}$ ArF excimer laser (Photon Machines Analyte 193) coupled to a quadrupole ICP-MS (Thermo Fisher Scientific iCAP Q) at the Mass Spectrometry Laboratory of the Andean Geothermal Center of Excellence (CEGA), Department of Geology, University of Chile. The analytical protocol is based on Román et al. (2019), with some modifications. Prior to each analytical session, the ICP-MS was tuned by ablating a NIST SRM 610 glass reference material (i.e., ${ }^{238} \mathrm{U}^{+}{ }^{232} \mathrm{Th}^{+}$between 0.95 and 1.05), oxide production $\left(\mathrm{ThO}^{+} / \mathrm{Th}^{+}<0.5 \%\right)$, and double-charged production $\left({ }^{22} \mathrm{M}^{+} /{ }^{44} \mathrm{Ca}^{++}<0.01 \%\right)$. Ablation was carried out using a laser pulse frequency of $4 \mathrm{~Hz}$, an energy density of $1.5 \mathrm{~J} / \mathrm{cm}^{2}$, and a spot size of 25,30 , or $40 \mu \mathrm{m}$. Pure He was used as a carrier gas. Each spot was ablated for $30 \mathrm{~s}$ following $30 \mathrm{~s}$ of gas background collection. The following isotopes were monitored: ${ }^{34} \mathrm{~S},{ }^{51} \mathrm{~V},{ }^{52} \mathrm{Cr},{ }^{53} \mathrm{Cr},{ }^{55} \mathrm{Mn},{ }^{57} \mathrm{Fe},{ }^{59} \mathrm{Co}$, ${ }^{60} \mathrm{Ni},{ }^{63} \mathrm{Cu},{ }^{65} \mathrm{Cu},{ }^{66} \mathrm{Zn},{ }^{69} \mathrm{Ga},{ }^{72} \mathrm{Ge},{ }^{73} \mathrm{Ge},{ }^{75} \mathrm{As},{ }^{77} \mathrm{Se},{ }^{82} \mathrm{Se}$, ${ }^{95} \mathrm{Mo},{ }^{97} \mathrm{Mo},{ }^{107} \mathrm{Ag},{ }^{109} \mathrm{Ag},{ }^{111} \mathrm{Cd},{ }^{115} \mathrm{In},{ }^{118} \mathrm{Sn},{ }^{120} \mathrm{Sn},{ }^{121} \mathrm{Sb}$, ${ }^{123} \mathrm{Sb},{ }^{125} \mathrm{Te},{ }^{182} \mathrm{~W},{ }^{197} \mathrm{Au},{ }^{202} \mathrm{Hg},{ }^{205} \mathrm{Tl},{ }^{206} \mathrm{~Pb},{ }^{207} \mathrm{~Pb}, 2{ }^{08} \mathrm{~Pb}$, and ${ }^{209} \mathrm{Bi}$, using a total quadrupole sweep time of $0.55 \mathrm{~s}$.

Both external and internal standard calibrations were applied (Longerich et al. 1996). The MASS-1 pressed synthetic sulfide reference material (Wilson et al. 2002) was used as a primary standard, and total $\mathrm{Fe}$ concentrations obtained by EPMA were used as the internal standard. Additionally, the GSE-1G glass reference material was employed as a secondary standard using the concentration values reported by Jochum et al. (2005). External standard measurements were performed at the beginning and end of each analysis round of 20 spot analyses. Data integration and reduction was carried out using LAtools, an open-source Python package (Branson et al. 2019), with some modifications. Detection limits were calculated based on the equations of Longerich et al. (1996). For some elements with very low background, values from Heinrich et al. (2003) were used as the detection limit. The MASS-1 reference material may contain some heterogeneities, especially for $\mathrm{Au}$ (Wilson et al. 2002). Therefore, LAICP-MS depth profiles of the MASS-1 reference material were thoroughly inspected before calibration to avoid introducing Au heterogeneities, and MASS- 1 readings were made in duplicate each analysis round. Except for the MASS-1 reference material, we did not exclude analyses affected by possible inclusions.

Supplementary Information The online version contains supplementary material available at https://doi.org/10.1007/s00126-021-01053-4.

Acknowledgements We thank H. Kon and R. Maekawa at Mitsui Kushikino Mining Co., Ltd., and K. Shinagawa, M. Inoue, and K. Yamamiya at Kasuga Mines Co., Ltd., for the sampling support in the 
Akeshi and Kasuga deposits. We gratefully acknowledge J. Torimoto, K. Uematsu, M. Yano, K. Fujinaga, and T. Nozaki for the help with sample preparation and EPMA analyses. We also thank faculty and student members of the Millennium Nucleus for Metal Tracing, University of Chile, for their dedicated support in LA-ICP-MS analysis and technical discussion. We appreciate J.W. Hedenquist and A. Arribas for their thorough and constructive reviews that significantly improved this manuscript.

Funding This research was financially supported by Japan Society for the Promotion of Science (JSPS) KAKENHI Grants No. JP15H05771 and JP20H05658 to Y.K., No. JP17H01361 to N.K., No. JP18K14168 to K.Y., and No. JP20J22038 to M.I. LA-ICP-MS analysis was supported by ANID-FONDEQUIP instrumentation grant EQM120098. Additional funding was provided by ANID through Millennium Science Initiative Program (NCN13_065). M.I. is grateful to the University of Tokyo School of Engineering Study Abroad Musha Shugyo Program for their financial support for travel to and stay in University of Chile.

Data and materials availability Not applicable.

Code availability Not applicable.

\section{Declarations}

Conflict of interest The authors declare no competing interests.

Open Access This article is licensed under a Creative Commons Attribution 4.0 International License, which permits use, sharing, adaptation, distribution and reproduction in any medium or format, as long as you give appropriate credit to the original author(s) and the source, provide a link to the Creative Commons licence, and indicate if changes were made. The images or other third party material in this article are included in the article's Creative Commons licence, unless indicated otherwise in a credit line to the material. If material is not included in the article's Creative Commons licence and your intended use is not permitted by statutory regulation or exceeds the permitted use, you will need to obtain permission directly from the copyright holder. To view a copy of this licence, visit http://creativecommons.org/licenses/by/4.0/.

\section{References}

Arribas A (1995) Characteristics of high-sulfidation epithermal deposits, and their relation to magmatic fluid. Mineral Assoc Can Short Course 23:419-454

Branson O, Fehrenbacher J, Vetter L, Sadekov AY, Eggins SM, Spero HJ (2019) LAtools: a data analysis package for the reproducible reduction of LA-ICPMS data. Chem Geol 504:83-95. https://doi.org/10. 1016/j.chemgeo.2018.10.029

Chouinard A, Paquette J, Williams-Jones AE (2005a) Crystallographic controls on trace-element incorporation in auriferous pyrite from the Pascua epithermal high-sulfidation deposit, Chile-Argentina. Can Mineral 43:951-963. https://doi.org/10.2113/gscanmin.43.3.951

Chouinard A, Williams-Jones AE, Leonardson RW, Hodgson CJ, Silva P, Téllez C, Vega J, Rojas F (2005b) Geology and genesis of the multistage high-sulfidation epithermal Pascua $\mathrm{Au}-\mathrm{Ag}-\mathrm{Cu}$ deposit, Chile and Argentina. Econ Geol 100:463-490. https://doi.org/10. 2113/gsecongeo.100.3.463

Ciobanu CL, Cook NJ, Utsunomiya S, Kogagwa M, Green L, Gilbert S, Wade B (2012) Gold-telluride nanoparticles revealed in arsenic-free pyrite. Am Mineral 97:1515-1518. https://doi.org/10.2138/am. 2012.4207
Cook NJ, Ciobanu CL, Mao J (2009) Textural control on gold distribution in As-free pyrite from the Dongping, Huangtuliang and Hougou gold deposits, North China Craton (Hebei Province, China). Chem Geol 264:101-121. https://doi.org/10.1016/j.chemgeo.2009.02.020

Deditius AP, Utsunomiya S, Renock D, Ewing RC, Ramana CV, Becker U, Kesler SE (2008) A proposed new type of arsenian pyrite: composition, nanostructure and geological significance. Geochim Cosmochim Acta 72:2919-2933. https://doi.org/10.1016/J.GCA. 2008.03.014

Deditius AP, Utsunomiya S, Ewing RC, Chryssoulis SL, Venter D, Kesler SE (2009a) Decoupled geochemical behavior of $\mathrm{As}$ and $\mathrm{Cu}$ in hydrothermal systems. Geology 37:707-710. https://doi.org/10. 1130/G25781A.1

Deditius AP, Utsunomiya S, Ewing RC, Kesler SE (2009b) Nanoscale "liquid" inclusions of As-Fe-S in arsenian pyrite. Am Mineral 94: 391-394. https://doi.org/10.2138/am.2009.3116

Deditius AP, Utsunomiya S, Reich M, Kesler SE, Ewing RC, Hough R, Walshe J (2011) Trace metal nanoparticles in pyrite. Ore Geol Rev 42:32-46. https://doi.org/10.1016/j.oregeorev.2011.03.003

Deditius AP, Reich M, Kesler SE, Utsunomiya S, Chryssoulis SL, Walshe J, Ewing RC (2014) The coupled geochemistry of Au and As in pyrite from hydrothermal ore deposits. Geochim Cosmochim Acta 140:644-670. https://doi.org/10.1016/j.gca.2014.05.045

Drummond SE, Ohmoto H (1985) Chemical evolution and mineral deposition in boiling hydrothermal systems. Econ Geol 80:126-147. https://doi.org/10.2113/gsecongeo.80.1.126

Faure K, Matsuhisa Y, Metsugi H, Mizota C, Hayashi S (2002) The Hishikari Au-Ag epithermal deposit, Japan: oxygen and hydrogen isotope evidence in determining the source of paleohydrothermal fluids. Econ Geol 97:481-498. https://doi.org/10.2113/gsecongeo. 97.3.481

Fleet ME, Mumin AH (1997) Gold-bearing arsenian pyrite and marcasite and arsenopyrite from Carlin Trend gold deposits and laboratory synthesis. Am Mineral 82:182-193. https://doi.org/10.2138/am1997-1-220

Fournier RO (1999) Hydrothermal processes related to movement of fluid from plastic into brittle rock in the magmatic-epithermal environment. Econ Geol 94:1193-1211. https://doi.org/10.2113/gsecongeo. 94.8.1193

Garwin S, Hall R, Watanabe Y (2005) Tectonic setting, geology, and gold and copper mineralization in Cenozoic magmatic arcs of Southeast Asia and the West Pacific. In: Hedenquist JW, Thompson JFH, Goldfarb RJ, Richards JP (eds) Economic Geology One Hundredth Anniversary Volume. Society of Economic Geologists, pp 891-930. https://doi.org/10.5382/ AV100.27

Gopon P, Douglas JO, Auger MA, Hansen L, Wade J, Cline JS, Robb LJ, Moody MP (2019) A nanoscale investigation of Carlin-type gold deposits: an atom-scale elemental and isotopic perspective. Econ Geol 114:1123-1133. https://doi.org/10.5382/econgeo.4676

Hedenquist JW, Aoki M (1991) Meteoric interaction with magmatic discharges in Japan and the significance for mineralization. Geology 19:1041-1044. https://doi.org/10.1130/0091-7613(1991) 019<1041:MIWMDI>2.3.CO;2

Hedenquist JW, Aoki M, Shinohara H (1994a) Flux of volatiles and oreforming metals from the magmatic-hydrothermal system of Satsuma Iwojima volcano. Geology 22:585-588. https://doi.org/10.1130/ 0091-7613(1994)022<0585:FOVAOF>2.3.CO;2

Hedenquist JW, Matsuhisa Y, Izawa E, White NC, Giggenbach WF, Aoki M (1994b) Geology, geochemistry, and origin of high sulfidation $\mathrm{Cu}-\mathrm{Au}$ mineralization in the Nansatsu district, Japan. Econ Geol 89:1-30. https://doi.org/10.2113/gsecongeo.89.1.1

Heinrich CA (2005) The physical and chemical evolution of low-salinity magmatic fluids at the porphyry to epithermal transition: a thermodynamic study. Mineral Deposita 39:864-889. https://doi.org/10. 1007/s00126-004-0461-9 
Heinrich CA, Pettke T, Halter WE, Aigner-Torres M, Audétat A, Günther D, Hattendorf B, Bleiner D, Guillong M, Horn I (2003) Quantitative multi-element analysis of minerals, fluid and melt inclusions by laser-ablation inductively-coupled-plasma mass-spectrometry. Geochim Cosmochim Acta 67:3473-3497. https://doi.org/10. 1016/S0016-7037(03)00084-X

Herazo A, Reich M, Barra F, Morata D, Id R (2021) Trace element geochemistry of pyrite from bitumen-bearing stratabound $\mathrm{Cu}-(\mathrm{Ag})$ deposits, Northern Chile. ACS Earth Space Chem 5:566-579. https://doi.org/10.1021/acsearthspacechem.0c00321

Huston DL, Sie SH, Suter GF, Cooke DR, Both RA (1995) Trace elements in sulfide minerals from eastern Australian volcanic-hosted massive sulfide deposits: part I. Proton microprobe analyses of pyrite, chalcopyrite, and sphalerite, and part II. Selenium levels in pyrite: comparison with $\delta^{34} \mathrm{~S}$ values and implications for the source of sulfur in volcanogenic hydrothermal systems. Econ Geol 90: 1167-1196. https://doi.org/10.2113/gsecongeo.90.5.1167

Imai H, Takahashi M, Yamaguchi M (1996) Relation between volcanichosted precious-and base-metal deposits and geothermal systems. Resour Geol 46:73-94. https://doi.org/10.11456/ shigenchishitsu1992.46.73

Izawa E (1992) Evolution of volcanic hydrothermal systems in southern Kyushu. Geol Surv Jpn Rep 279:84-88. https://www.gsj.jp/data/ rep-gsj/No279.pdf

Izawa E, Hayashi T (2018) Potential for porphyry copper mineralization below the Kasuga lithocap, Nansatsu district, Japan. Resour Geol 68:181-194. https://doi.org/10.1111/rge.12163

Izawa E, Urashima Y, Okubo Y (1984) Age of mineralization of the Nansatsu type gold deposits, Kagoshima, Japan-K-Ar dating of alunite from Kasuga, Iwato and Akeshi. Min Geol 34:343-351. https://doi.org/10.11456/shigenchishitsu1951.34.343

Izawa E, Urashima Y, Ibaraki K, Suzuki R, Yokoyama T, Kawasaki K, Koga A, Taguchi S (1990) The Hishikari gold deposit: high-grade epithermal veins in Quaternary volcanics of southern Kyushu, Japan. J Geochem Explor 36:1-56. https://doi.org/10.1016/03756742(90)90050-K

Jochum KP, Willbold M, Raczek I, Stoll B, Herwig K (2005) Chemical characterisation of the USGS reference glasses GSA-1G, GSC-1G, GSD-1G, GSE-1G, BCR-2G, BHVO-2G and BIR-1G ysing EPMA, ID-TIMS, ID-ICP-MS and LA-ICP-MS. Geostand Geoanal Res 29:285-302. https://doi.org/10.1111/j.1751-908x. 2005.tb00901.x

King J, Williams-Jones AE, van Hinsberg V, Williams-Jones G (2014) High-sulfidation epithermal pyrite-hosted $\mathrm{Au}(\mathrm{Ag}-\mathrm{Cu})$ ore formation by condensed magmatic vapors on Sangihe Island, Indonesia. Econ Geol 109:1705-1733. https://doi.org/10.2113/econgeo.109.6. 1705

Kouzmanov K, Pokrovski GS (2012) Hydrothermal Controls on Metal Distribution in Porphyry Cu (-Mo-Au) Systems In: Hedenquist JW, Harris M, Camus F (eds) Geology and Genesis of Major Copper Deposits and Districts of the World: A Tribute to Richard H Sillitoe. Society of Economic Geologists, pp 573-618. https://doi.org/10. 5382/SP.16.22

Krupp RE, Seward TM (1987) The Rotokawa geothermal system, New Zealand: an active epithermal gold-depositing environment. Econ Geol 82:1109-1129. https://doi.org/10.2113/gsecongeo.82.5.1109

Kusebauch C, Gleeson SA, Oelze M (2019) Coupled partitioning of Au and As into pyrite controls formation of giant Au deposits. Sci Adv 5:eaav5891. https://doi.org/10.1126/sciadv.aav5891

Liu W, McPhail DC (2005) Thermodynamic properties of copper chloride complexes and copper transport in magmatic-hydrothermal solutions. Chem Geol 221:21-39. https://doi.org/10.1016/j.chemgeo. 2005.04.009

Longerich HP, Jackson SE, Günther D (1996) Laser ablation inductively coupled plasma mass spectrometric transient signal data acquisition and analyte concentration calculation. J Anal At Spectrom 11:899904. https://doi.org/10.1039/JA9961100899

Mahony SH, Wallace LM, Miyoshi M, Villamor P, Sparks RJ, Hasenaka $\mathrm{T}$ (2011) Volcano-tectonic interactions during rapid plate-boundary evolution in the Kyushu region, SW Japan. Bull Geol Soc Am 123: 2201-2223. https://doi.org/10.1130/B30408.1

Manceau A, Merkulova M, Mathon O, Glatzel P, Murdzek M, Batanova V, Simionovici A, Steinmann SN, Paktunc D (2020) The mode of incorporation of $\mathrm{As}(-\mathrm{I})$ and $\mathrm{Se}(-\mathrm{I})$ in natural pyrite revisited. ACS Earth Space Chem 4:379-390. https://doi.org/10.1021/ acsearthspacechem.9b00301

Metal Mining Agency of Japan (1993) Report on the detailed geological survey in the Nansatsu area in the fiscal year Heisei 4.

Morishita Y, Shimada N, Shimada K (2018) Invisible gold in arsenian pyrite from the high-grade Hishikari gold deposit, Japan: significance of variation and distribution of $\mathrm{Au} / \mathrm{As}$ ratios in pyrite. Ore Geol Rev 95:79-93. https://doi.org/10.1016/J.OREGEOREV. 2018.02.029

Morishita Y, Hammond NQ, Momii K, Konagaya R, Sano Y, Takahata N, Ueno H (2019) Invisible gold in pyrite from epithermal, bandediron-formation-hosted, and sedimentary gold deposits: evidence of hydrothermal influence. Minerals 9:447-447. https://doi.org/10. 3390/min9070447

Nakamura K, Yamanaka K, Yamasaki T (1994) Gold mineralization of the Akeshi mine, Kagoshima prefecture. Resour Geol 44:155-171. https://doi.org/10.11456/shigenchishitsu1992.44.155

Pacevski A, Libowitzky E, Zivkovic P, Dimitrijevic R, Cvetkovic L (2008) Copper-bearing pyrite from the Čoka Marin polymetallic deposit, Serbia: mineral inclusions or true solid-solution? Can Mineral 46:249-261. https://doi.org/10.3749/canmin.46.1.249

Peterson EC, Mavrogenes JA (2014) Linking high-grade gold mineralization to earthquake-induced faultvalve processes in the Porgera gold deposit, Papua New Guinea. Geology 42:383-386. https:// doi.org/10.1130/G35286.1

Pokrovski GS, Akinfiev NN, Borisova AY, Zotov AV, Kouzmanov K (2014) Gold speciation and transport in geological fluids: insights from experiments and physical-chemical modelling. Geol Soc Lond, Spec Publ 402:9-70. https://doi.org/10.1144/SP402.4

Pokrovski GS, Kokh MA, Proux O, Hazemann JL, Bazarkina EF, Testemale D, Escoda C, Boiron MC, Blanchard M, Aigouy T, Gouy S, de Parseval P, Thibaut M (2019) The nature and partitioning of invisible gold in the pyrite-fluid system. Ore Geol Rev 109:545-563. https://doi.org/10.1016/j.oregeorev.2019.04.024

Putnis A (2009) Mineral replacement reactions. Rev Mineral Geochem 70:87-124. https://doi.org/10.2138/rmg.2009.70.3

Reich M, Becker U (2006) First-principles calculations of the thermodynamic mixing properties of arsenic incorporation into pyrite and marcasite. Chem Geol 225:278-290. https://doi.org/10.1016/j. chemgeo.2005.08.021

Reich M, Kesler SE, Utsunomiya S, Palenik CS, Chryssoulis SL, Ewing RC (2005) Solubility of gold in arsenian pyrite. Geochim Cosmochim Acta 69:2781-2796. https://doi.org/10.1016/j.gca. 2005.01 .011

Reich M, Deditius A, Chryssoulis S, Li J-W, Ma C-Q, Parada MA, Barra F, Mittermayr F (2013) Pyrite as a record of hydrothermal fluid evolution in a porphyry copper system: a SIMS/EMPA trace element study. Geochim Cosmochim Acta 104:42-62. https://doi.org/ 10.1016/j.gca.2012.11.006

Renard F, Røyne A, Putnis CV (2019) Timescales of interface-coupled dissolution-precipitation reactions on carbonates. Geosci Front 10: 17-27. https://doi.org/10.1016/j.gsf.2018.02.013

Román N, Reich M, Leisen M, Morata D, Barra F, Deditius AP (2019) Geochemical and micro-textural fingerprints of boiling in pyrite. Geochim Cosmochim Acta 246:60-85. https://doi.org/10.1016/J. GCA.2018.11.034 
Rottier B, Kouzmanov K, Wälle M, Bendezú R, Fontboté L (2016) Sulfide replacement processes revealed by textural and LA-ICPMS trace element analyses: example from the early mineralization stages at Cerro de Pasco, Peru. Econ Geol 111:1347-1367. https:// doi.org/10.2113/econgeo.111.6.1347

Sanchez-Alfaro P, Reich M, Driesner T, Cembrano J, Arancibia G, PérezFlores P, Heinrich CA, Rowland J, Tardani D, Lange D, Campos E (2016) The optimal windows for seismically-enhanced gold precipitation in the epithermal environment. Ore Geol Rev 79:463-473. https://doi.org/10.1016/j.oregeorev.2016.06.005

Savage KS, Tingle TN, O'Day PA, Waychunas GA, Bird DK (2000) Arsenic speciation in pyrite and secondary weathering phases, Mother Lode Gold District, Tuolumne County, California. Appl Geochem 15:1219-1244. https://doi.org/10.1016/S0883-2927(99) 00115-8

Shinohara H, Giggenbach WF, Kazahaya K, Hedenquist JW (1993) Geochemistry of volcanic gases and hot springs of SatsumaIwojima, Japan: following Matsuo. Geochem J 27:271-285. https://doi.org/10.2343/geochemj.27.271

Sillitoe RH (1985) Ore-related breccias in volcanoplutonic arcs. Econ Geol 80:1467-1514. https://doi.org/10.2113/gsecongeo.80.6.1467

Simmons SF, Brown KL, Tutolo BM (2016) Hydrothermal transport of $\mathrm{Ag}, \mathrm{Au}, \mathrm{Cu}, \mathrm{Pb}, \mathrm{Te}, \mathrm{Zn}$, and other metals and metalloids in New Zealand geothermal systems: spatial patterns, fluid-mineral equilibria, and implications for epithermal mineralization. Econ Geol 111: 589-618. https://doi.org/10.2113/econgeo.111.3.589

Simon G, Huang H, Penner-Hahn JE, Kesler SE, Kao L-S (1999a) Oxidation state of gold and arsenic in gold-bearing arsenian pyrite. Am Mineral 84:1071-1079. https://doi.org/10.2138/am-1999-7-809

Simon G, Kesler SE, Chryssoulis S (1999b) Geochemistry and textures of gold-bearing arsenian pyrite, Twin Creeks, Nevada: implications for deposition of gold in Carlin-type deposits. Econ Geol 94:405-422. https://doi.org/10.2113/gsecongeo.94.3.405

Spycher NF, Reed MH (1989) Evolution of a Broadlands-type epithermal ore fluid along alternative P-T paths: implications for the transport and deposition of base, precious, and volatile metals. Econ Geol 84: 328-359. https://doi.org/10.2113/gsecongeo.84.2.328

Stoffregen R (1987) Genesis of acid-sulfate alteration and $\mathrm{Au}-\mathrm{Cu}-\mathrm{Ag}$ mineralization at Summitville, Colorado. Econ Geol 82:15751591. https://doi.org/10.2113/gsecongeo.82.6.1575

Takeda T, Shimada N, Ueno H (2001) Paleomagnetic constraints on mineralization age of the Nansatsu-type gold deposits in Southern Kyushu, Japan. Resour Geol 51:239-248. https://doi.org/10.1111/j. 1751-3928.2001.tb00095.x

Takenouchi S (1983) Fluid inclusion study of the Nansatsu-type gold deposits, Southern Kyushu. Min Geol 33:237-245. https://doi.org/ 10.11456/shigenchishitsu1951.33.237
Tardani D, Reich M, Deditius AP, Chryssoulis S, Sánchez-Alfaro P, Wrage J, Roberts MP (2017) Copper-arsenic decoupling in an active geothermal system: a link between pyrite and fluid composition. Geochim Cosmochim Acta 204:179-204. https://doi.org/10.1016/J. GCA.2017.01.044

Tokunaga M (1954) Geology and ore deposits of the Kasuga mine and Akeshi mine, in the Makurazaki district, Kagoshima Prefecture. Min Geol 4:205-212. https://doi.org/10.11456/shigenchishitsu1951.4. 14_205

Tooth B, Ciobanu CL, Green L, O’Neill B, Brugger J (2011) Bi-melt formation and gold scavenging from hydrothermal fluids: an experimental study. Geochim Cosmochim Acta 75:5423-5443. https:// doi.org/10.1016/j.gca.2011.07.020

Vennemann TW, Muntean JL, Kesler SE, O’Neil JR, Valley JW, Russell N (1993) Stable isotope evidence for magmatic fluids in the Pueblo Viejo epithermal acid sulfate Au-Ag deposit, Dominican Republic. Econ Geol 88:55-71. https://doi.org/10.2113/gsecongeo.88.1.55

Watanabe Y (2005) Late Cenozoic evolution of epithermal gold metallogenic provinces in Kyushu, Japan. Mineral Deposita 40: 307-323. https://doi.org/10.1007/s00126-005-0025-7

Watanabe Y, Sato R, Sulaksono A (2018) Role of potassic alteration for porphyry $\mathrm{Cu}$ mineralization: implication for the absence of porphyry Cu deposits in Japan. Resour Geol 68:195-207. https://doi.org/10. $1111 /$ rge. 12165

Widler AM, Seward TM (2002) The adsorption of gold(I) hydrosulphide complexes by iron sulphide surfaces. Geochim Cosmochim Acta 66:383-402. https://doi.org/10.1016/S0016-7037(01)00791-8

Wilson SA, Ridley WI, Koenig AE (2002) Development of sulfide calibration standards for the laser ablation inductively-coupled plasma mass spectrometry technique. J Anal At Spectrom 17:406-409. https://doi.org/10.1039/b108787h

Wu Y-F, Evans K, Li J-W, Fougerouse D, Large RR, Guagliardo P (2019a) Metal remobilization and ore-fluid perturbation during episodic replacement of auriferous pyrite from an epizonal orogenic gold deposit. Geochim Cosmochim Acta 245:98-117. https://doi. org/10.1016/J.GCA.2018.10.031

Wu Y-F, Fougerouse D, Evans K, Reddy SM, Saxey DW, Guagliardo P, Li J-W (2019b) Gold, arsenic, and copper zoning in pyrite: a record of fluid chemistry and growth kinetics. Geology 47:641-644. https://doi.org/10.1130/G46114.1

Publisher's note Springer Nature remains neutral with regard to jurisdictional claims in published maps and institutional affiliations. 